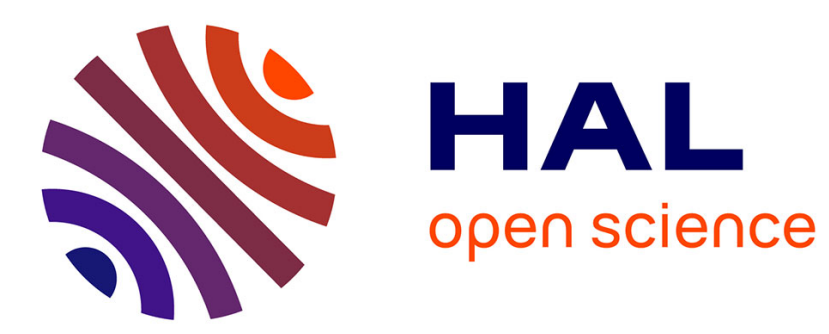

\title{
Enantioselective Hydrogenation of Activated Aryl Imines Catalyzed by an Iron(II) P-NH-P' Complex
}

Chris Seo, Thibault Tannoux, Samantha Smith, Alan Lough, Robert Morris

\section{To cite this version:}

Chris Seo, Thibault Tannoux, Samantha Smith, Alan Lough, Robert Morris. Enantioselective Hydrogenation of Activated Aryl Imines Catalyzed by an Iron(II) P-NH-P' Complex. Journal of Organic Chemistry, 2019, 84 (18), pp.12040-12049. 10.1021/acs.joc.9b01964 . hal-02473966

\section{HAL Id: hal-02473966 \\ https://hal-univ-rennes1.archives-ouvertes.fr/hal-02473966}

Submitted on 20 Mar 2020

HAL is a multi-disciplinary open access archive for the deposit and dissemination of scientific research documents, whether they are published or not. The documents may come from teaching and research institutions in France or abroad, or from public or private research centers.
L'archive ouverte pluridisciplinaire HAL, est destinée au dépôt et à la diffusion de documents scientifiques de niveau recherche, publiés ou non, émanant des établissements d'enseignement et de recherche français ou étrangers, des laboratoires publics ou privés. 


\title{
Enantioselective Hydrogenation of Activated Aryl Imines Catalyzed by an Iron(II) P-NH-P' Complex
}

Chris S. G. Seo, ${ }^{\dagger}$ Thibault Tannoux, ${ }^{\ddagger}$ Samantha A. M. Smith, ${ }^{\dagger}$ Alan J. Lough ${ }^{\dagger}$ and Robert H. Morris ${ }^{\dagger *}$

${ }^{\dagger}$ Department of Chemistry, University of Toronto, 80 Saint George St., Toronto, Ont. Canada M5S 3H6.

‡ UFR Sciences et Propriétés de la Matière, Université de Rennes 1, 35042 Rennes CEDEX France.

*rmorris@chem.utoronto.ca

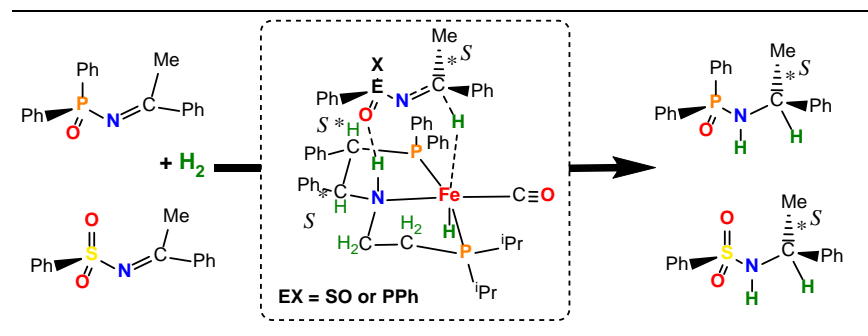

\begin{abstract}
Chiral amines are key building blocks in synthetic chemistry with numerous applications in the agricultural and pharmaceutical industries. Asymmetric imine hydrogenation, particularly with iridium catalysts, is well developed. However, imine reduction still remains challenging in the context of replacing such a precious metal with a cheap, nontoxic, and environmentally friendly substitute such as iron. Here we report that an unsymmetrical iron P-NH-P' catalyst that was previously shown to be effective for the asymmetric hydrogenation of aryl ketones is also a very effective catalyst for the asymmetric hydrogenation of prochiral aryl imines activated with $N$-diphenylphosphinoyl or $N$-tosyl groups. The P-NH-P' abbreviation stands for $(S, S)-\mathrm{PPh}_{2} \mathrm{CHPhCHPhNHCH}_{2} \mathrm{CH}_{2} \mathrm{P}^{\mathrm{P}} \mathrm{Pr}$. DFT results suggest that, surprisingly, the $\mathrm{NH}$ group on the catalyst activates and orients the imine to hydride attack by hydrogen-bonding to the PO or SO group on the imine nitrogen, as opposed to the imine nitrogen itself. This may explain why $N$-Ph and $N$-Bu imines are not hydrogenated.
\end{abstract}

\section{INTRODUCTION}

The preparation of enantiopure amines is important for providing synthetic building blocks for bioactive molecules and chiral auxiliaries. The asymmetric hydrogenation $(\mathrm{AH})$ of imines represents one of the most direct and atom economical approaches. The significance of asymmetric imine hydrogenation in the context of pharmaceutical and agricultural industries has been reviewed extensively. ${ }^{1-8}$ To date, large scale AH processes have been predominantly developed with precious metal catalysts based primarily on iridium, ${ }^{9-12}$ and rhodium ${ }^{13}$ while ruthenium complexes are often used in asymmetric transfer hydrogenation (ATH) processes. ${ }^{10,14,15}$

Imines are generally challenging substrates to reduce in a stereoselective manner. They are prone to isomerization between $\mathrm{E}$ and $\mathrm{Z}$ forms. As the amine product builds up in the AH process, it can coordinate to the metal and inhibit catalysis by preventing dihydrogen coordination. In order to counter this, placing a bulky sulfonyl or diphenylphosphinoyl substituent on the imine nitrogen can hinder the binding of the substrate and product amine to the metal. These groups also have the advantage of activating the imine to hydride attack by increasing the electrophilicity of the imine carbon. The nitrogen substituent is readily cleaved to produce valuable homochiral amines. ${ }^{16}$ Thus activated imine catalytic AH has received attention with complexes based on rhodium, ${ }^{16}$ palladium, ${ }^{17-21}$ and ruthenium. ${ }^{22}$ 
Reports of the use of first row transition metal complexes for the catalytic AH of imine are limited. In 2011 Beller and coworkers reported that a range of $N$-aryl substituted imines were hydrogenated to amines with ee ranging from 88 to $98 \%$ using Knölker’s iron complex $\mathrm{FeH}(\mathrm{CO})_{2}\left(\mathrm{Cp}{ }^{\prime} \mathrm{OH}\right)(5 \mathrm{~mol} \%)$ in combination with the homochiral phosphoric acid (S)-TRIP (1 mol\%) at 50 bar $\mathrm{H}_{2}$ and $65^{\circ} \mathrm{C}^{23}$ In 2014 our group reported that an iron complex $\left[\mathrm{FeBr}(\mathrm{CO})_{2}\left(\mathrm{~L}^{1}\right)\right] \mathrm{BF}_{4}$ with the asymmetric ligand $(S, S)-\mathrm{PPh}_{2} \mathrm{CHPhCHMeNHCH}_{2} \mathrm{CH}_{2} \mathrm{P}^{\mathrm{i}} \mathrm{Pr}_{2}\left(\mathrm{~L}^{1}\right)$ when activated with $\mathrm{LiAlH}_{4} /$ iso-amylalcohol was active in the presence of $10 \mathrm{~mol} \% \mathrm{KO}{ }^{\mathrm{t}} \mathrm{Bu}$ for the $\mathrm{AH}$ of the $\mathrm{N}$-diphenylphosphinoyl imine derived from 1-propiophenone to the amine ( $90 \%$ ee ) at $20 \mathrm{~atm} \mathrm{H}_{2}$ and $50{ }^{\circ} \mathrm{C}^{24}$ Bai et al have described the use of homochiral cyclopentadienone)iron complex for the $\mathrm{AH}$ of activated imines but the enantioselectivity was poor (ee of the amine up to $40 \%$ ). ${ }^{25}$ Otherwise there have been several reports of the ATH of activated imines by catalysts based on iron, ${ }^{26-29}$ cobalt $^{30,31}$ and nickel. ${ }^{32}$

\section{RESULTS AND DISCUSSION}

In pursuit of a highly enantioselective iron catalyst for direct hydrogenation, our group found that the iron complex $\mathrm{FeHCl}(\mathrm{CO})(\mathrm{P}-\mathrm{NH}-\mathrm{P}$ ') $\mathbf{1}$

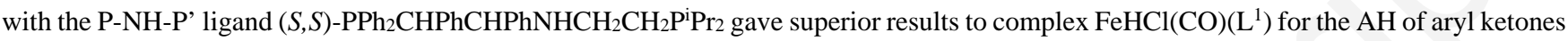
and was easier to synthesize. ${ }^{33}$ Here we report that the iron complex 1 permits the highly enantioselective hydrogenation of a range of activated imines.

We chose the (E)- $N$-diphenylphosphinoyl imine derived from acetophenone (2a) as the model substrate, and probed various catalytic conditions for hydrogenation (Table 1). An increase in the catalyst loading from $1 \mathrm{~mol} \%$ to $3 \mathrm{~mol} \%$ with a KO'Bu loading of $10 \mathrm{~mol} \%$ in toluene at $80^{\circ} \mathrm{C}$ under 30 bar of hydrogen pressure resulted in a systematic increase in the yield of product after 20 h.(entries 2-4) Increasing the base to catalyst ratio reduced the yield and caused a degradation in the ee (entries 1-2); this suggests that a large excess of base to catalyst may cause undesirable side reactions. The optimal catalytic condition resulted in an 85\% yield of the amine in $98.3 \%$ ee (S) (entry 4). The use of 15 bar $\mathrm{H}_{2}$ gave a slightly lower yield of amine with the identical ee, suggesting a minor dependence of hydrogen concentration on the rate of the reaction. There was no degradation of ee in the product on going from $10 \mathrm{~h}$ of reaction with $64 \%$ isolated yield (entry 6 ) to $20 \mathrm{~h}$ with 85\% yield (entry 4). The influence of various bases was examined (entries 7-10). Alkali metal tert-butoxides gave similar results while catalysis with potassium hydroxide resulted in a product with a slightly degraded ee. These results suggest that the Lewis acidity of the alkali metal cation is not a factor. No reaction was observed when potassium carbonate was used. The solvents THF and EtOH were less effective, giving lower yields and ee (entries 11 and 12) while iPrOH gave comparable reactivity and stereoselectivity as the toluene system (entry 13).

With the optimized reaction condition in hand, we investigated the scope of the AH with respect to the prochiral imine structures (Table 2). In general, the substrates were reduced with high enantioselectivity (90-99\%). A lower yield and ee was observed with added bulk on the alkyl group (2a versus $\mathbf{2 b )}$ ). Substrates with a naphthyl group (2c and 2d) were reduced with exceptionally high ee of 98\% and 99\%. The addition of an electron withdrawing chloro substituent at the para- or meta-position of the aryl ring (2e and 2f) resulted in a higher yield but similar ee compared to that of an electron donating methoxy group at the para- or ortho-position (2g and $2 \mathbf{h}$ ). Additionally, the oxygen- or sulfur-containing heterocycle-substituted $N$-phosphinoylimines (2i-k) could be reduced to amines with at least $90 \%$ ee. The thiophene substituent was well tolerated; however the 5-chloro-2-thiophene and furyl derivatives underwent side reactions that resulted in a lower yield of the amine product. Amine $3 \mathbf{l}$ derived from indanone was obtained in low yield and in moderate ee (79 \%), and 3m, derived from 2-heptanone, in low yield and low ee.

Next, we investigated the catalytic performance of the iron complex 1 with ketimines with various substituents on the imine nitrogen. The AH of the $N$-tosylimine (4a) produced the amine in comparable yield and ee to $N$-phosphinoylimines. The product amine (5a) was recrystallized and characterized by X-ray crystallography to reveal the absolute configuration to be $(S)$. The cyclic $N$-sulfonylimine derived from saccharine (4b) was resistant to AH and afforded a low yield of amine with low enantioselectivity. The $N$-phenylimine (4c) and $N$-butylimine (4d) could not be hydrogenated under these conditions. 
Table 1. Optimization of Catalytic Conditions for the Iron-catalyzed AH of Imine $2 a^{a}$

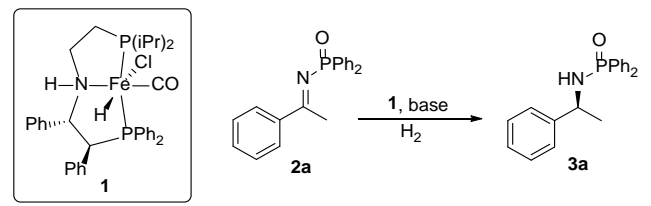

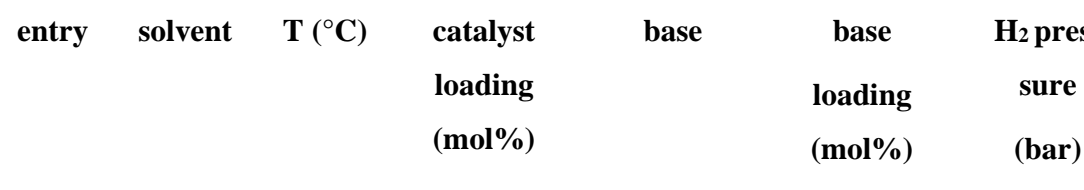

\begin{tabular}{lllll}
\hline 1 & Toluene & 80 & 1 & $\mathrm{KO}^{\mathrm{t}} \mathrm{Bu}$
\end{tabular}

2 Toluene $80 \quad 1$

3 Toluene $80 \quad 2$

4 Toluene $80 \quad 3$

5 Toluene $\quad 80 \quad 3$

$6 \quad$ Toluene $\quad 80 \quad 3$

7 Toluene 80

8 Toluene 80

$9 \quad$ Toluene 80

10 Toluene 80

11 THF $\quad 60 \quad 3$

$12 \quad \mathrm{EtOH} \quad 80 \quad 3$

$\begin{array}{llll}13 & \mathrm{iPrOH} & 80 & 3\end{array}$
$\mathrm{KO}{ }^{\mathrm{t} B u}$

$\mathrm{KO}^{\mathrm{t}} \mathrm{Bu}$

$\mathrm{KO}^{\mathrm{t}} \mathrm{Bu}$

$\mathrm{KO}{ }^{t} \mathrm{Bu}$

$\mathrm{KO}{ }^{t} \mathrm{Bu}$

$\mathrm{NaO}^{t} \mathrm{Bu}$

$\mathrm{LiO}^{t} \mathrm{Bu}$

$\mathrm{KOH}$

$\mathrm{K}_{2} \mathrm{CO}_{3}$

$\mathrm{KO}{ }^{t} \mathrm{Bu}$

$\mathrm{KO}{ }^{\mathrm{t} B u}$

$\mathrm{KO} B \mathrm{Bu}$

30

30

30

30

15

30

10

30

20

30

20

30

20

30

20

30

20

30

20

30

20 excess was determined by HPLC on a chiral stationary phase. 
Table 2. Iron-catalyzed AH of $N$-diphenylphosphinoyl Ketimines

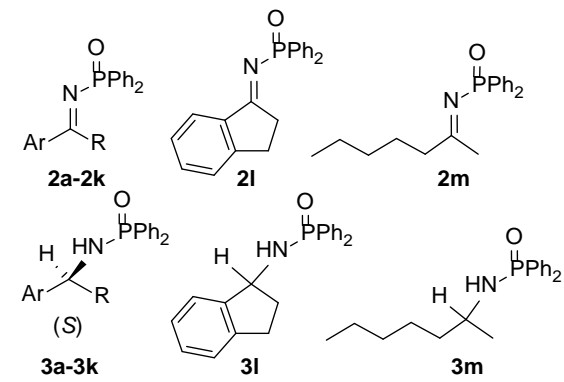

entry $\quad \mathrm{Ar} / \mathrm{R} \quad$ Yield of $\mathbf{3} \quad$ ee (\%) of 3

\begin{tabular}{cccc} 
& & $(\%)$ & $(S)^{\mathrm{b}}$ \\
\hline 1 & Phenyl/Me (2a) & 85 & 98 \\
2 & Phenyl/Et (2b) & 81 & 94 \\
3 & 1-naphthyl/Me (2c) & 85 & 99 \\
4 & 2-naphthyl/Me (2d) & 78 & 98 \\
5 & p-chlorophenyl/Me & 84 & 98
\end{tabular}

(2e)

6 m-chlorophenyl/Me

81

94

(2f)

$7 \quad$-methoxyphenyl/Me

76

96

(2g)

8

o-methoxyphenyl/Me

74

96

(2h)

9

2-furyl/Me (2i)

58

92

10 2-thiophene/Me (2j)

82

$95^{c}$

11 5-chloro-2-thio-

59

90

phene/Me (2k)

12

2l

42

79

13

$2 \mathrm{~m}$

14

35

$\bar{a}$ The reactions were performed with $3.87 \mu \mathrm{mol}$ of catalyst $(3 \mathrm{~mol} \%), 0.0129 \mathrm{mmol} \mathrm{KO}{ }^{\mathrm{t}} \mathrm{Bu}(10 \mathrm{~mol} \%), 0.129 \mathrm{mmol}$ substrate, 30 bar of $\mathrm{H}_{2}$, $6 \mathrm{~mL}$ of toluene, $80^{\circ} \mathrm{C}, 20 \mathrm{~h} .^{\mathrm{b}}$ Enantiomeric excess was determined by HPLC on a chiral stationary phase. ${ }^{\mathrm{c}}$ The absolute configuration was determined to be $(S)$ by single crystal X-ray crystallography. 
Table 3. Iron-catalyzed AH of $N$-tosyl, Cyclic $N$-sulfonyl and $N$-aryl and $N$-Butyl Ketimines ${ }^{\text {a }}$

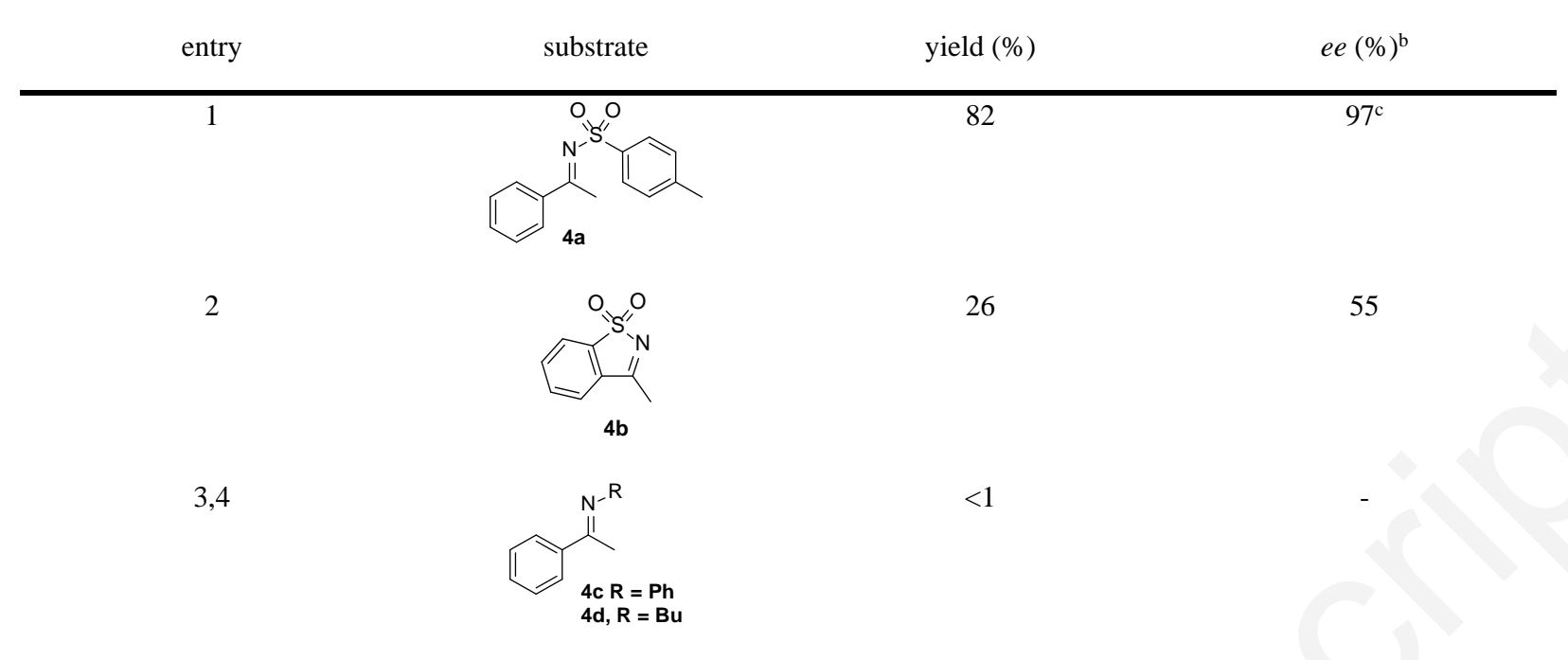

\footnotetext{
a-c See the footnotes of Table 2 .
}

In order to gain insight into the catalytic mechanism, density functional theory (DFT) calculations were performed using the M11L functional with the inclusion of toluene solvation. The favored mechanism, as shown in an abbreviated fashion in Scheme 1, where the trans-dihydride $\mathbf{8}$ transfers a hydride to the imine in the outer coordination sphere. Complex $\mathbf{8}$ is proposed to form from the catalyst precursor $\mathbf{1}$ by the heterolytic splitting of dihydrogen to the added base, presumably via complex $\left[\mathrm{FeH}\left(\mathrm{H}_{2}\right) \mathrm{L}\right](\mathrm{OtBu}) 7$ when KOtBu is used. The heterolytic splitting of the $\eta^{2}-\mathrm{H}_{2}$ ligand via $\mathbf{T S}^{\mathbf{E}}$ produces the dihydride $\mathbf{8}$. The turnover-limiting transfer of a hydride $\mathbf{8}$ to the imine via $\mathbf{T S}^{\mathbf{A}}$ for the phosphinoylimine (Figure 1) or $\mathbf{T S}^{\mathbf{C}}$ for the $N$-sulfonylimine $N$-1-phenylethylidene-phenylsulfonamide (imine2, Figure 2) results in the formation of an outer-sphere, ion-paired amide complex $\mathbf{9}$ with an Fe-NH...O hydrogen bond. The NH proton remains on the nitrogen. The amine can form by protonation of the amide by an alcohol complex [FeH(OHtBu)(CO)(P-NH-P')]+ (Scheme 2).

A notable feature of this mechanism is the hydrogen bond formed between the $\mathrm{N}-\mathrm{H}$ proton on the $\mathrm{P}-\mathrm{NH}-\mathrm{P}$ ' ligand and the $\mathrm{P}=\mathrm{O}$ moiety of the $\mathrm{N}$-phosphinoyl group in $\mathbf{T S}^{\mathbf{A}}$ or a $\mathrm{S}=\mathrm{O}$ moiety of the $\mathrm{N}$-sulfonyl group in $\mathbf{T S}^{\mathbf{C}}$ to form an eight-membered transition state. The NH-O interaction helps activate the imine carbon to nucleophilic attack and enhances the enantioinduction by anchoring the substrate to the catalyst. This type of ligand-substrate interaction in activated imine hydrogenation has not been proposed previously. The closest case is the proposed $\mathrm{Al}-\mathrm{O}=\mathrm{P}$ interaction of $\mathrm{N}$-phosphinoylimines in aluminum-mediated stoichiometric reductions. ${ }^{34}$ In the previous studies of FeH2(CO)(P-NHP') complexes, the enantiodetermining step in the AH of ketones was proposed on the basis of density functional calculations (DFT) to be hydride transfer to the ketone which is hydrogen-bonded to the $\mathrm{NH}$ of the $\mathrm{P}-\mathrm{NH}-\mathrm{P}$ ' ligand (Figure 1 , TS $^{\mathbf{B}}$ ). ${ }^{33,35}$ Similarly, The $\mathrm{N}-\mathrm{H}$ proton is commonly proposed to interact with the imine nitrogen and act as proton donor to unactivated imines. ${ }^{36-38}$ However the nitrogen of these activated imines are sterically hindered and not basic. The TS structure TS $^{\mathbf{G}-\mathbf{S}}$ with the imine nitrogen of imine2 accepting a hydrogen bond from the catalyst’s NH (Figure S5) has an energy that is $7 \mathrm{kcal} / \mathrm{mol}$ higher in energy than that of TS ${ }^{\mathrm{C}-\mathrm{S}}$ and a TS frequency of $-1150 \mathrm{~cm}^{-1}$. This could be the explanation for the inactivity of the catalyst toward $N$-phenyl and $N$-butyl imine hydrogenation where a comparable activation is not present. 
Scheme 1. Proposed Catalytic Cycle for the Asymmetric Imine Hydrogenation Catalyzed by an Iron P-NH-P' Complex.

$$
\mathrm{KO}_{\mathrm{B}}^{\mathrm{Bu}} \stackrel{1}{\downarrow}-\mathrm{KCl}
$$
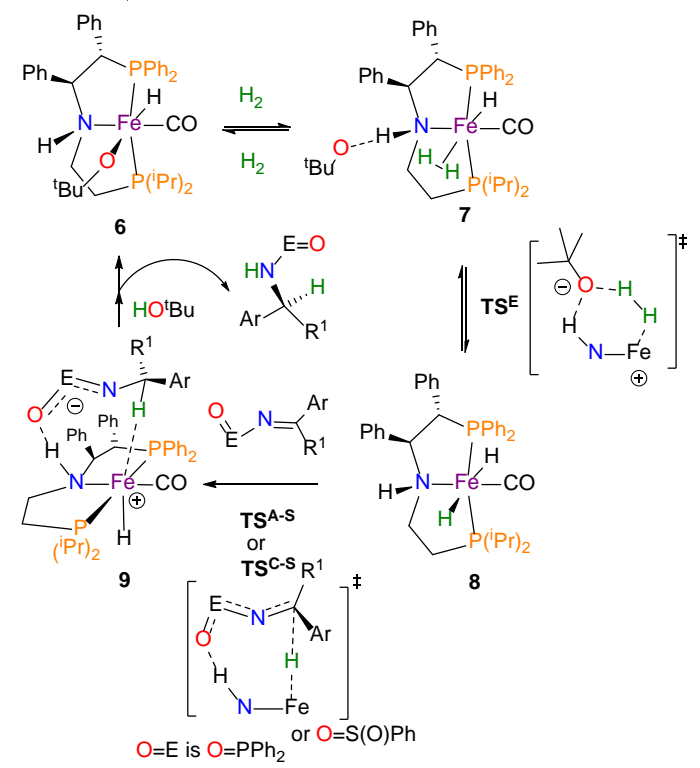

Similar to the ketone hydrogenation transition state $\mathbf{T S}^{\mathbf{B}},{ }^{33}$ the smaller methyl group on the substrate in $\mathbf{T S}^{\mathbf{A}}$ or $\mathbf{T S}^{\mathrm{C}}$ is pushed against a phenyl of the $\mathrm{PPh}_{2}$ group while the larger phenyl substituent on the imine carbon is oriented toward the open side of the catalyst (Figures 1, 2). The hydride addition results in the $(S)$ configuration of the amine. For the imine, the aryl of the sulfonyl group or a phenyl of the OPPh2 group fits into a gap between the $\mathrm{P}^{\mathrm{P}} \mathrm{Pr} 2$ group and the axial NH group.

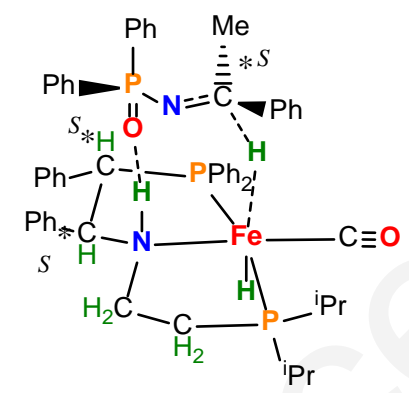

TS $^{A-S}$

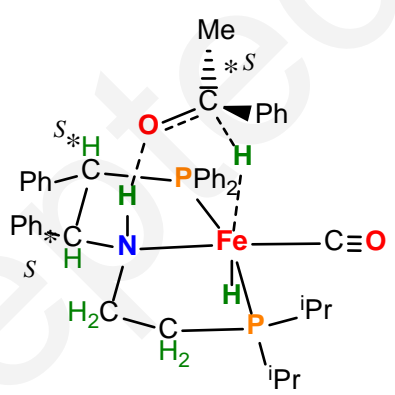

TS $^{B}$

Figure 1. The proposed transition state structure (TS ${ }^{\mathrm{A}-\mathrm{S}}$ ) for the transfer of a hydride from the dihydride complex to the activated $N$-phosphinoylimine 2a compared with that to acetophenone (TS $\left.{ }^{\mathbf{B}}\right)$ to give the $(S)$ imine or alcohol, respectively. 


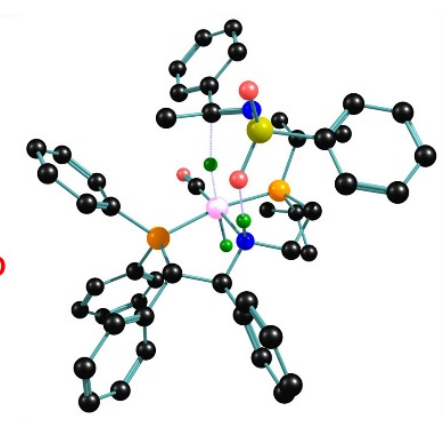

Figure 2. The proposed transition state $\left(\mathbf{T S}^{\mathrm{C}-\mathrm{S}}\right.$ ) for the hydride transfer from iron to imine2 (ChemDraw view and ChemCraft view with

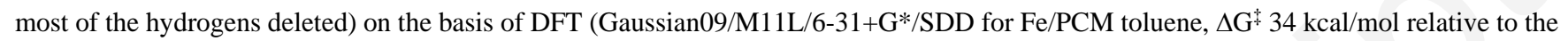
dihydride and free imine, $531 \mathrm{i} \mathrm{cm}^{-1}, 80^{\circ} \mathrm{C}$ ). Selected bond distances around the 8 membered substrate-catalyst interaction: Fe...H 1.66 , H...C 1.77, C-N 1.32, N-S 1.60, S-O 1.45, O...H 1.97, H-N 1.03, N-Fe $2.05 \AA$.

A complete cycle (Scheme 2) was calculated for the AH of imine2 to the amine $S$ - $\mathrm{PhMeCHNHSO}{ }_{2} \mathrm{Ph}$ (amine2) and the free energy profile of the reaction is shown in Figure 3. The alkoxide complex $\mathbf{6}$ is the turn-over limiting intermediate, the lowest point in the reaction profile. The splitting of dihydrogen to the alkoxide via $\mathbf{T S}^{\mathrm{E}}$ is a lower energy process than the hydride transfer $\mathbf{T S}^{\mathrm{C}-\mathrm{S}}$. Therefore the energy span of the reaction is $27 \mathrm{kcal} / \mathrm{mol}$, consistent with a reaction requiring a temperature above ambient. The off-cycle amido complex $\mathbf{1 5}$ with the amide $N$-bonded to iron, as shown in the center of the cycle, is sterically hindered and is only $4 \mathrm{kcal} / \mathrm{mol}$ more stable than the outersphere amide complex $\mathbf{9}$ and is not a stable species relative to the coordinated tBuOH complex $\mathbf{1 3}$ or the alkoxide complex $\mathbf{6}$ plus the amine2 product. This is not the case for the catalytic cycle involving the hydrogenation of the cyclic $N$-sulfonylimine $4 \mathbf{b}$ where the amide, when $N$ bonded to iron in the amido complex 16 (Figure 4), is more stable than the alkoxide complex (plus the energies of the imine plus $\mathrm{H}_{2}$ ). Thus the most stable species in the cycles are the alkoxide complex $\mathbf{6}$, or in the case of the small imine $\mathbf{4 b}$, the amido complex $\mathbf{1 6}$. The need for the ratio $\mathrm{KO}^{\mathrm{t}} \mathrm{Bu}: \mathrm{Fe}$ 3.3:1 may reflect a balance between favoring the dihydrogen splitting process by an increase in concentration of the base and inhibiting dihydrogen coordination by competitive coordination of the alkoxide to the iron in $\mathbf{6}$. 
Scheme 2. Possible Catalytic Cycle for the AH of imine2 Where the Dihydride Complex 8 Transfers a Hydride to the Imine in TS ${ }^{\mathrm{C}-}$

s (the Turnover Limiting Transition State) and Dihydrogen is Split by an Outersphere Alkoxide Group in TS $^{\mathrm{E}}$.

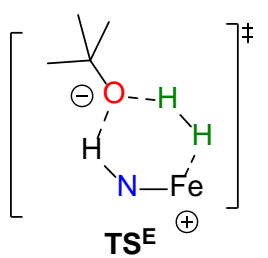<smiles>CC1(C)CCCC1</smiles>
íPh $\mathrm{Ph}$

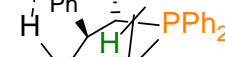

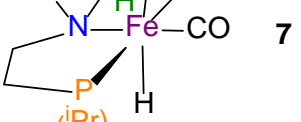

$(\mathrm{Pr})_{2}$

$\mathrm{H}_{2}$

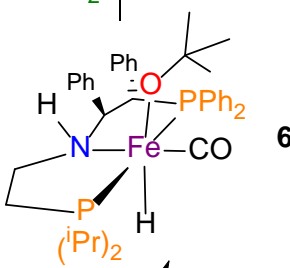

6

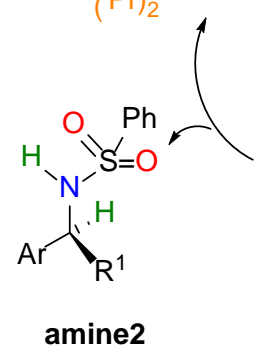

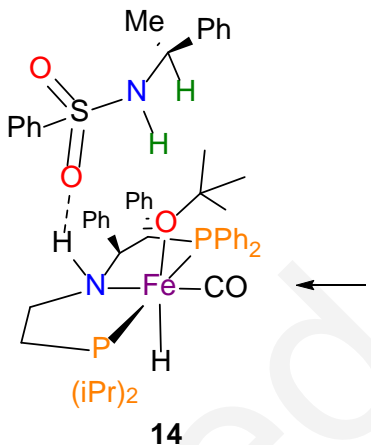

14

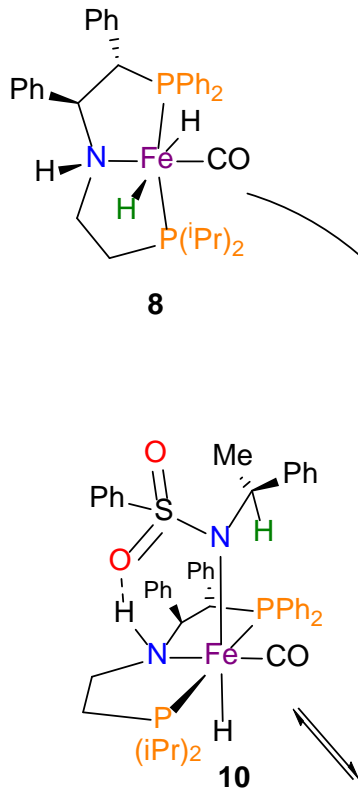

$\mathrm{O} \mathrm{Ph}$

$\mathrm{HOtBu}$

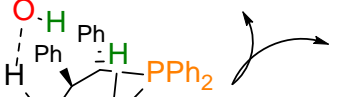

15
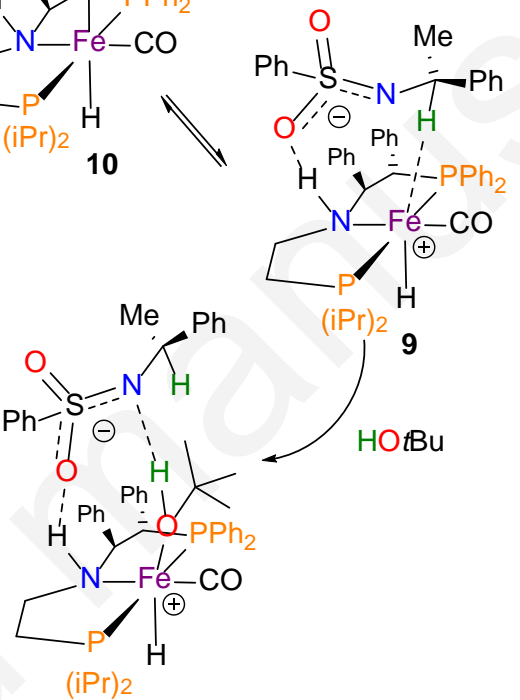

13 


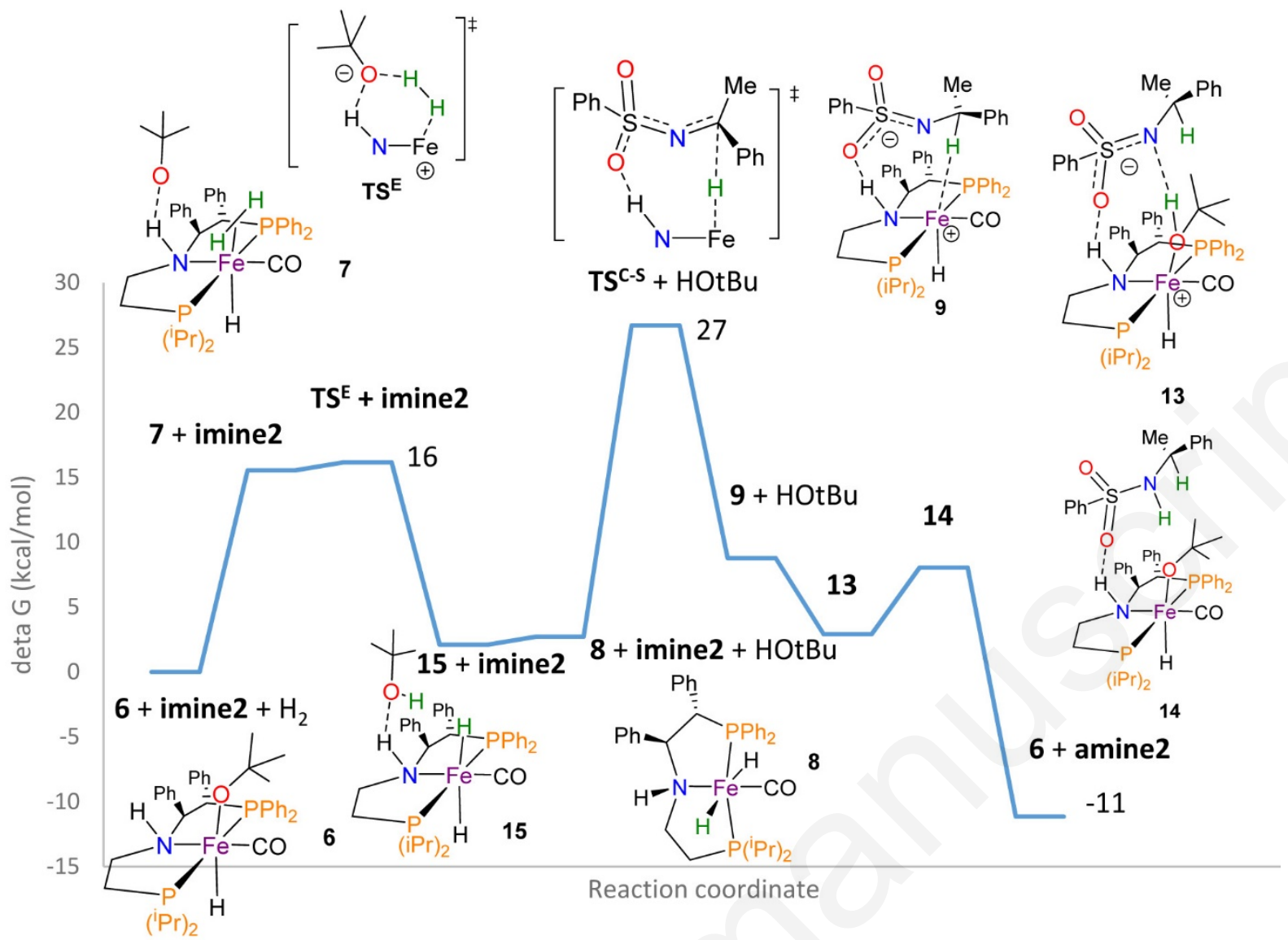

Figure 3. Reaction coordinate diagram corresponding to the catalytic cycle shown in Scheme 2.

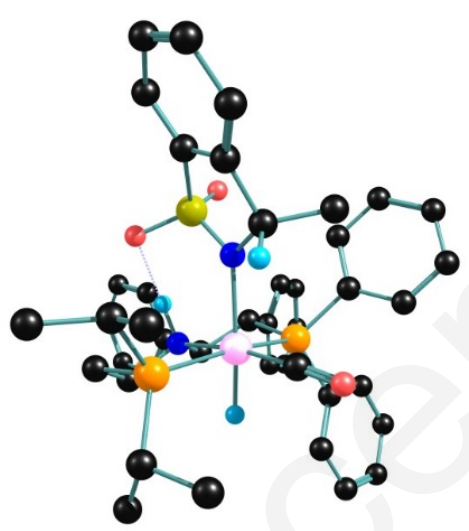

Figure 4. Structure of the amido complex 16, with the amide form of $(S)$-amine $5 \mathbf{b}$ coordinated to [FeH(CO)(P-NH-P’) $]^{+}$. Non-essential hydrogens have been deleted for the sake of clarity.

Attack on the opposite face of the imine via TS $^{\text {A-R }}$ (Figure 5) or TS ${ }^{\mathbf{C}-\mathbf{R}}$ (Figure S2) produces a transition state 6-7 kcal/mol higher in energy than that of $\mathbf{T S}^{\mathrm{A}-\mathrm{S}}$ or $\mathbf{T S}^{\mathrm{C}-\mathrm{S}}$; the pro- $R$ calculated structures have the larger phenyl group against the $\mathrm{PPh}_{2}$ phenyl. Calculations of the hydride transfer to the cyclic $N$-sulfonylimine $\mathbf{4 b}$ gave a small energy difference between pro-S (TS $\mathbf{T S}^{\mathbf{F}-\mathbf{S}}$ ) and $R$ (TS ${ }^{\mathbf{F}-\mathbf{R}}$ ) transition states caused by the more compact size of the substrate (Figure S3). 


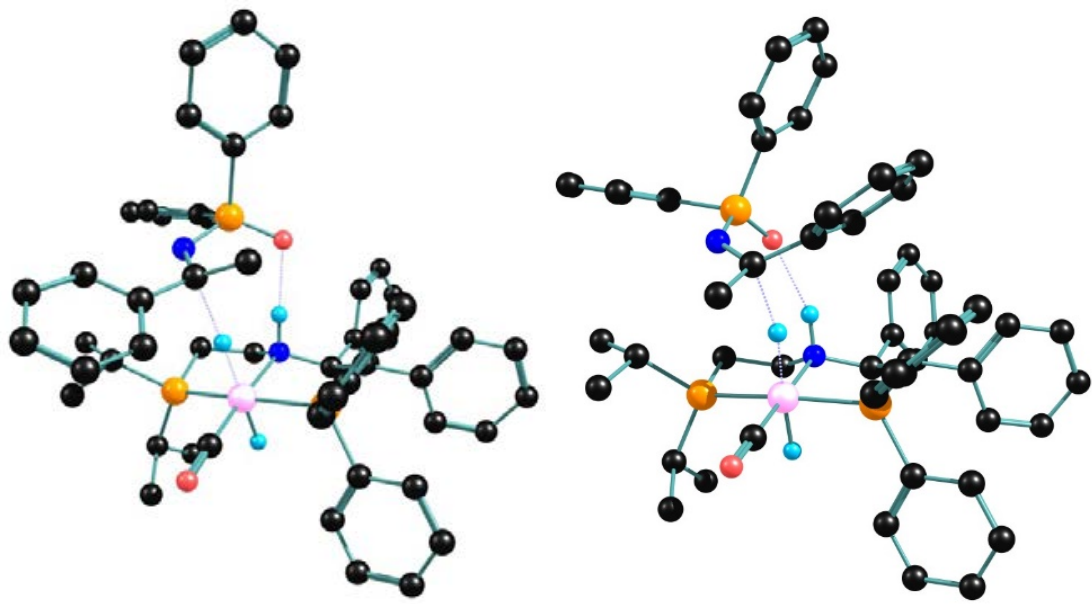

Figure 5. Structure of the proposed pro-S transition state (at left) $\mathbf{T S}^{\mathrm{A}-\mathrm{S}}\left(522 i \mathrm{~cm}^{-1}\right)$ and pro- $R$ transition state (at right) $\mathbf{T S}^{\mathrm{A}-\mathrm{R}}\left(544 i \mathrm{~cm}^{-1}\right)$ for the hydride transfer to the $N$-phosphinoyl imine 2a from the $\mathrm{FeH}_{2}(\mathrm{CO})\left(\mathrm{P}-\mathrm{NH}-\mathrm{P}^{\prime}\right)$ catalyst 8. Non-essential hydrogens have been deleted for the sake of clarity. TS $^{\mathrm{A}-\mathrm{S}}$ is $29 \mathrm{kcal} / \mathrm{mol}$ relative to complex 8 plus imine or $32 \mathrm{kcal} / \mathrm{mol}$ relative to Fe-O'Bu complex 6; $\mathbf{T S}^{\mathrm{A}-\mathrm{R}} 38$ $\mathrm{kcal} / \mathrm{mol}$.

Figure 6 shows the energy span of the reaction from the lowest energy species in the system: from the alkoxide complex $\mathbf{6}$ or the amido complex FeHL(S-amide3) $\mathbf{1 6}$ to the enantio-determining hydride transfer to imine transition state (TS) for the imines, imine1 (2a) imine2 $\left(\mathrm{PhMeC}=\mathrm{NSO}_{2} \mathrm{Ph}\right)$ and imine3 $(\mathbf{4 b})$ where $[\mathrm{FeHL}]^{+}$(amide) ${ }^{-}$is $\mathbf{9}$ in Scheme 1. Thus the net reactions correspond to:

$$
\begin{aligned}
& \text { Imine1 + FeH(OtBu)L }+\mathrm{H}_{2} \rightarrow[\mathrm{FeHL}]^{+}(\text {amide1 })^{-}+\mathrm{HOtBu}\left(\text { via } \text { TS }^{\mathrm{A}-\mathrm{S}} \text { or } \text { TS }^{\mathrm{A}-\mathrm{R}}\right. \text { ) } \\
& \text { Imine2 }+\mathrm{FeH}(\mathrm{OtBu}) \mathrm{L}+\mathrm{H}_{2} \rightarrow[\mathrm{FeHL}]^{+}\left(\text {amide2) }{ }^{-}+\mathrm{HOtBu}\left(\text { via } \text { TS }^{\mathrm{C}-\mathrm{S}} \text { or } \text { TS }^{\mathrm{C}-\mathrm{R}}\right. \text { ) }\right. \\
& \text { Imine3 + FeH(amide3) } \mathrm{L}+\mathrm{H}_{2} \rightarrow[\mathrm{FeHL}]^{+} \text {(amide3) }{ }^{-}+\text {amine3 (via } \mathbf{T S}^{\mathrm{F}-\mathrm{S}} \text { or } \mathbf{T S}^{\mathrm{F}-\mathrm{R}} \text { ) }
\end{aligned}
$$

The pro-S transition state for imine1 is found to be $6 \mathrm{kcal} / \mathrm{mol}$ lower in energy than the pro- $R$, representing a theoretical ee of $99.9 \%(S)$ ion reasonable agreement with the experimental value of $98 \%$ ee (S). The energy span of $32 \mathrm{kcal} / \mathrm{mol}$ is consistent with the experimental conditions where $353 \mathrm{~K}$ is required for the reaction to proceed. The alkoxide complex $\mathbf{6}$ was found to be lower in energy than the dihydride complex 8 plus free HOtBu by $2.7 \mathrm{kcal} / \mathrm{mol}$ (also true for imine2 but not shown in Figure 6). Similarly the pro-S transition state for imine2 is found to be $7 \mathrm{kcal} / \mathrm{mol}$ lower in energy than the pro- $R$, consistent with the observed ee of $97 \%(S)$ for the amine $\mathbf{5 a}$ from imine $\mathbf{4 a}$. The possibility that $t \mathrm{BuOH}$ shuttles a proton from the catalyst $\mathrm{NH}$ to the imine when the hydride transfers from iron to the imine carbon was investigated but all structures were found to be too crowded to allow the imine to approach to receive the proton. The energy span for the more compact imine3 (4b) is determined starting from the amido complex 16 produced from a previous hydride transfer step and going to the $\mathrm{TS}^{\mathrm{F}}$ transition states; the amido complex $\mathbf{1 6}$ is lower in energy than alkoxide complex $\mathbf{6}$ in this case when additional components are added to conserve the number of atoms. No difference was calculated for the pro- $R$ and pro-S transition states for the AH of imine3, consistent with the low ee of $55 \%$ (S) for amine $\mathbf{5 b}$ which represents a $\Delta \mathrm{G}$ of $0.8 \mathrm{kcal} / \mathrm{mol}$, within the error range of the calculation. In all cases the hydride transfer occurs before a proton transfer to the imine. 


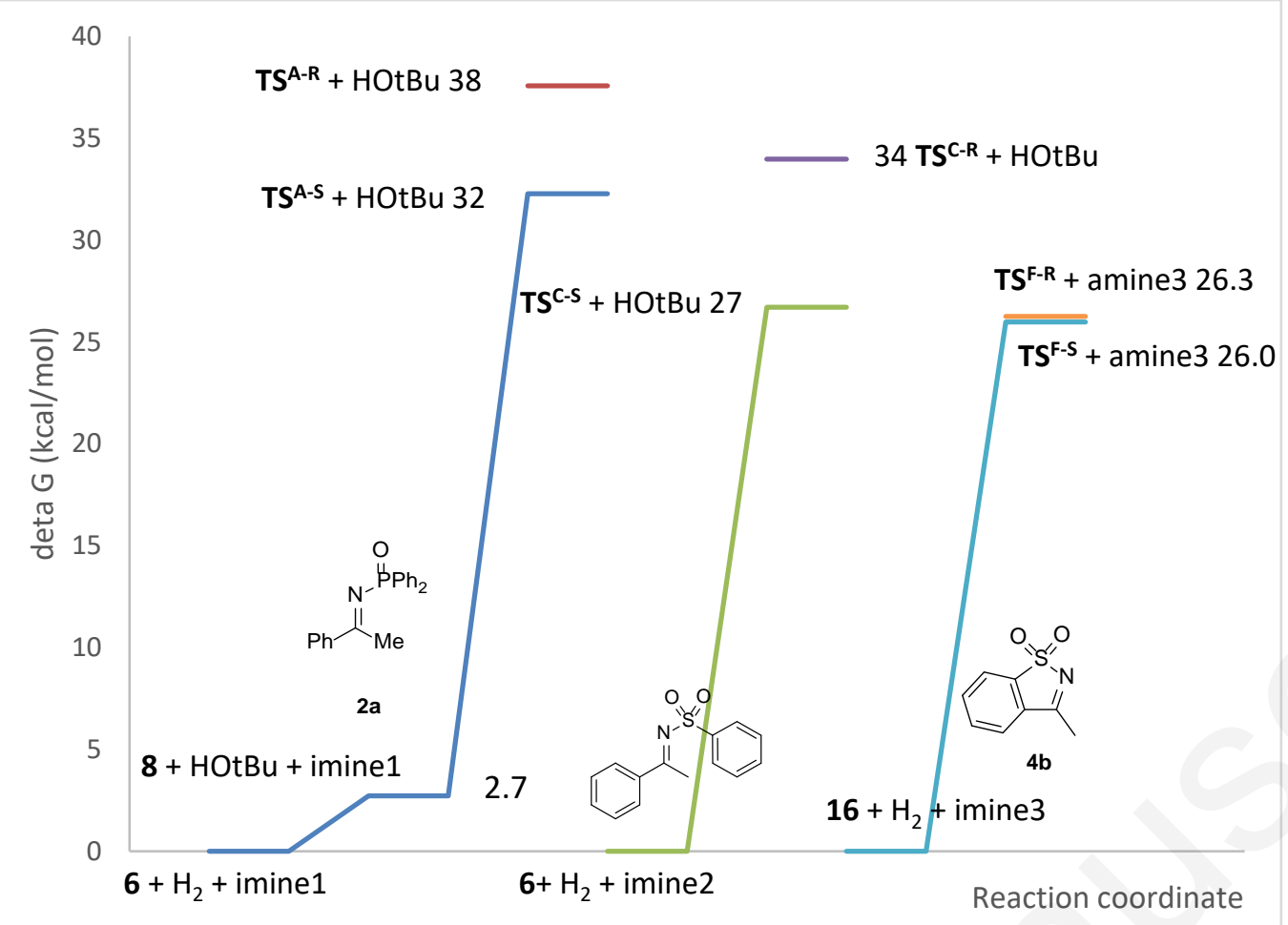

Figure 6. The energy span of the catalysis for three imines, representing also the enantiodetermining hydride transfer transition state.

An alternative route is one where dihydrogen splits heterolytically between the cationic Fe(II) center and the amide of complex $\mathbf{9}$ to reform the dihydride $\mathbf{8}$ via $\mathbf{T S}^{\mathbf{D}}$ (Figure 7) and where the outer-sphere amide form of the substrate is protonated giving the amine product directly. The energetics of this mechanism (Figure 8) are similar to those of alkoxide mechanism (Figure 3 ) but now the $\mathrm{H}_{2}$ splitting step is the turnover limiting transition state. After the precatalyst $\mathbf{1}$ is activated by $\mathrm{KOtBu}$, this route may also be operational.

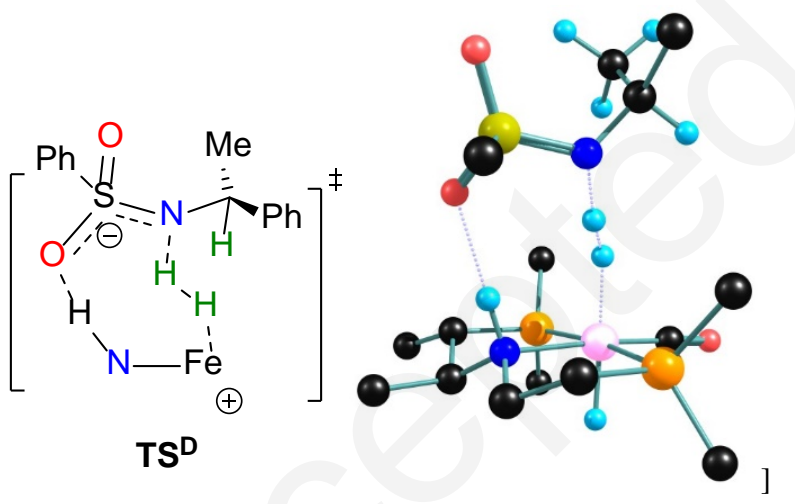

Figure 7. An alternative transition state $\mathbf{T S}^{\mathbf{D}}$ for the heterolytic splitting of dihydrogen to the outersphere sulfonylamide. 


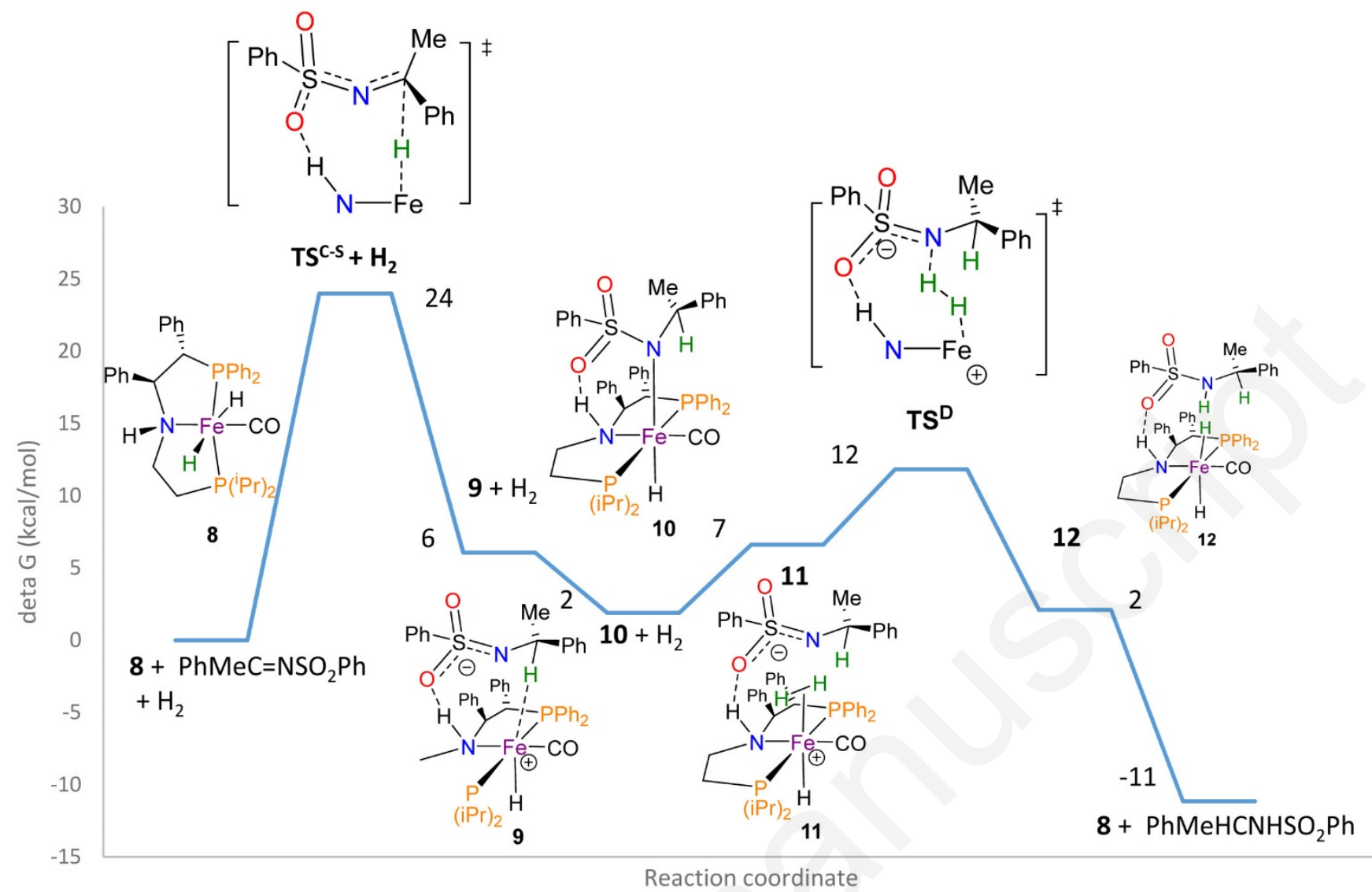

Figure 8. Reaction coordinate diagram $(\mathrm{kcal} / \mathrm{mol})$ for a model catalytic cycle for the asymmetric hydrogenation of imine2 catalyzed by the $\mathrm{FeH}_{2}(\mathrm{CO})(\mathrm{P}-\mathrm{NH}-\mathrm{P}$ ') catalyst 8 where dihydrogen splits into a hydride on iron and a proton on the nitrogen of the outer sphere amide form of the substrate. The $\mathrm{H}_{2}$ splitting transition state structure is shown with non essential atoms deleted for clarity. See also Figure $\mathrm{S} 4$ for the complete cycle.

We did not find an energetically reasonable mechanism that involved the dissociation of an arm of the tridentate ligand to allow an inner sphere hydride transfer. Inner sphere mechanisms involving dissociation of a ligand to let the bulky imine coordinate and allow hydride migration to the imine carbon were deemed too costly energetically since they involve the breaking of an iron-phosphorus bond and then the high transition state energy for hydride transfer in a very crowded system. The weaker iron-phosphorus bond would be the one to the homochiral $\mathrm{PPh}_{2} \mathrm{CHPh}$ part of the ligand; the loss of this bond would likely result in poor enantioinduction. The possibility of paramagnetic species was ruled out by calculating the energies of the $S=1$ and $S=2$ structures for the five coordinate iron complex $\mathbf{9}$, the most likely to have an open shell. The $\mathrm{S}=1$ is $18.2 \mathrm{kcal} / \mathrm{mol}$ higher in energy than $\mathbf{9}$ with $\mathrm{S}=0$, and the $\mathrm{S}=2,30.8 \mathrm{kcal} / \mathrm{mol}$ higher in energy than 9 .

\section{CONCLUSION}

We have found a well-defined base-metal precatalyst $\mathrm{FeH}(\mathrm{Cl}) \mathrm{CO}(\mathrm{P}-\mathrm{NH}-\mathrm{P}$ ') $\mathbf{1}$ for the enantioselective synthesis of a range of $N$-phosphinoyl and $N$-tosyl aryl amines by AH. This catalyst has two phenyl groups on the ligand backbone to lock a five membered ring $(S, S)$ $\mathrm{PPh}_{2} \mathrm{CHPhCHPhNFe} \mathrm{into} \mathrm{a} \mathrm{rigid} \mathrm{chiral} \mathrm{array} \mathrm{of} \mathrm{phenyl} \mathrm{groups} \mathrm{to} \mathrm{interact} \mathrm{with} \mathrm{the} \mathrm{imine} \mathrm{substrate.} \mathrm{It} \mathrm{enters} \mathrm{the} \mathrm{catalytic} \mathrm{cycle} \mathrm{more} \mathrm{directly}$ than a previously reported $\left[\mathrm{FeBr}(\mathrm{CO})_{2}\left(\mathrm{~L}^{1}\right)\right] \mathrm{BF}_{4}$ system that does not have a hydride or $\mathrm{NH}$ group and $\mathbf{1}$ is more enantioselective than the previous version that had a more flexible ligand backbone with a smaller methyl and phenyl on the backbone. The small, cyclic imine $\mathbf{4 b}$ is proposed, on the basis of DFT calculations to form a stable amido iron complex after the hydride transfer which limits turnover. The other activated imines are bulky enough to avoid forming such a stable complex so that a tertiary-butoxide complex becomes the turnover limiting intermediate according the calculations. The calculations revealed that the role of the oxygen of the substituent on the activated imine nitrogen is to hydrogen bond with the $\mathrm{N}-\mathrm{H}$ group of the iron catalyst and participate in anchoring the pro-S face of the $\mathrm{C}=\mathrm{N}$ bond over the hydride. The hydride transfer transition state with an eight membered -Fe-H-CNEO-HN- ring structure is turnover- and enantio-determining. 
$N$-phenyl and $N$-butyl imines were not reduced using 1 possibly because they are not electrophilic enough and cannot form this ring for hydride transfer. This new information provides insight into ligand design for future AH catalysts.

\section{EXPERIMENTAL SECTION}

General information. All manipulations that involved air- or moisture-sensitive materials were performed using Schlenk techniques or a glovebox under an argon or nitrogen atmosphere. All solvents were degassed and dried using standard procedures prior to all manipulations and reactions unless stated otherwise. ${ }^{39}$ (1S,2S)-2-(diphenylphosphino)-1,2-diphenylethylamine was purchased from ACROS Organics and Iron catalyst $\mathbf{1}$ was prepared according to the previous literature. ${ }^{33}$ The catalyst is air sensitive as a solid and in solution. It is stable in a pure nitrogen or argon atmosphere indefinitely. It should be weighed in a glovebox. (E)-1-Phenyl- $N$-tosylethanimine (4a) and 3-methyl-1,2benzisothiazole 1,1-dioxide (4b) were prepared using previously reported procedure by Wang and coworkers. ${ }^{18}$ (E)-N-(1-Phenylethylidene)aniline (4c) was prepared from acetophenone and aniline in toluene. ${ }^{40} \mathrm{~N}$-(1-Phenylethylidene)butylamine (4d) was prepared using acetophenone, $\mathrm{N}$-butylamine and titanium tetrachloride in diethyl ether and dichloromethane. ${ }^{41}$ Deuterated solvents were purchased from Cambridge Isotope Laboratories, INC, and dried over activated molecular sieves. Column chromatography was performed with SiliaFlash P60 40-63 um silica gel from SilicycleTM.

NMR spectra of the samples that were prepared under argon in degassed solvents were recorded at ambient temperature and pressure using a Bruker Advance III $400 \mathrm{MHz}$, Agilent DD2 $500 \mathrm{MHz}$ or Agilent DD2 $600 \mathrm{MHz}$ spectrometer. ${ }^{1} \mathrm{H}$ NMR spectra were internally referenced to tetramethylsilane resonance (TMS, $0 \mathrm{ppm}$ ). ${ }^{13} \mathrm{C}\left\{{ }^{1} \mathrm{H}\right\}$ NMR spectra were referenced to solvent carbon resonances. Data for ${ }^{1} \mathrm{H}$ NMR spectra are reported as follows: chemical shift $(\delta \mathrm{ppm})$, multiplicity $(\mathrm{s}=$ singlet, $\mathrm{d}=$ doublet, $\mathrm{t}=$ triplet, $\mathrm{q}=$ quartet, $\mathrm{m}=$ multiplet, br = broad), coupling constant (Hz), integration. Enantiomeric excesses (ee) were determined by HPLC analysis performed on an Agilent HP 1100 Series modular system operated by ChemStation LC 3D software, v.10.02. on chiral column DAICEL CHIRALPAK AD-H. Enantiomeric purity (reported as \% ee) was determined by comparison with the racemic assay and calculated as follows:

$\%$ ee $=[($ Area A - Area B $) /($ Area A + Area B $)] \times 100$.

General procedure for preparation of $\mathrm{N}$-phosphinoylimines. $N$-phosphinoylimines were prepared using modified procedure from previous literature. ${ }^{42,43}$ A representative example is the synthesis of (S)- $N$-(1-phenylethyl)diphenylphosphinamide (2a). A suspension of hydroxylamine hydrochloride $(2.78 \mathrm{~g}, 40 \mathrm{mmol})$ and sodium acetate $(4.10 \mathrm{~g}, 50 \mathrm{~mol})$ in $80 \%$ aqueous ethanol solution $(25 \mathrm{~mL})$ was stirred at $25^{\circ} \mathrm{C}$ for 30 minutes. Then, acetophenone $(2.9 \mathrm{~mL}, 25 \mathrm{mmol})$ was added and the reaction mixture was heated to reflux for 3 hours. It was cooled down, evaporated of all volatiles under the vacuum and the residue was put through a short silica pad. The filtrate was concentrated in vacuo to yield crystalline oxime. It was used without further purification.

In a Schlenk flask, oxime was dissolved in a mixture of DCM and hexanes $(1: 1,50 \mathrm{~mL})$ and the solution was cooled down to $-41^{\circ} \mathrm{C}$ with MeCN/dry ice. Triethylamine (3.8 mL, $27.5 \mathrm{mmol})$ was added dropwise, followed by chlorodiphenylphosphine (4.9 mL, $27.5 \mathrm{mmol})$. The reaction mixture was stirred overnight, concomitantly warming to room temperature. All volatiles were evaporated in vacuum and filtered over a short pad of Celite, washed with $2 \times 20 \mathrm{~mL}$ of DCM. The filtrate was extracted with $2 \times 20 \mathrm{~mL}$ water and $20 \mathrm{~mL}$ brine and dried over anhydrous $\mathrm{MgSO}_{4}$. The organic layer was concentrated in vacuo to afford the crude ketimine. It was purified with column chromatography (1:1 = ethyl acetate:hexanes), and recrystallized with benzene/hexanes to yield $2 \mathbf{a}$.

The characterization of $N$-phosphinoylimines $2 \mathbf{a},{ }^{43} \mathbf{2 b},{ }^{27} \mathbf{2 c},{ }^{27} \mathbf{2 d},{ }^{27} \mathbf{2 e},{ }^{43} \mathbf{2 f},{ }^{43} \mathbf{2 g},{ }^{43} \mathbf{2 h},{ }^{43} \mathbf{2} \mathbf{i},{ }^{44} \mathbf{2 j},{ }^{27} \mathbf{2} \mathbf{k},{ }^{27} \mathbf{2} \mathbf{l}^{27}$ and $2 \mathbf{m}^{26}$ was consistent with those previously reported in the literature. Racemic mixture of $\mathrm{N}$-phosphinoylamines were prepared by $\mathrm{NaBH}_{4}$ reduction of the respective imines.

General procedure for asymmetric reduction of imines. All of the hydrogenation reactions were performed at constant pressures using a stainless steel $50 \mathrm{~mL}$ Parr hydrogenation reactor. The reactor was maintained at the appropriate temperature in oil bath. The reactor was flushed several times with hydrogen gas at 10 bar prior to addition of catalyst and substrate solution, and base solution. In an argon glovebox, a vial with stir bar was charged with the catalyst $1\left(2.5 \mathrm{mg}, 3.87 \times 10^{-3} \mathrm{mmol}\right)$, substrate $\left(1.29 \times 10^{-1} \mathrm{mmol}\right)$ and $3 \mathrm{~mL}$ toluene. For base solution, a separate vial was charged with $\mathrm{KOtBu}\left(1.4 \mathrm{mg}, 1.29 \times 10^{-2} \mathrm{mmol}\right)$ and $3 \mathrm{~mL}$ toluene. The solutions were stirred for 5 minutes and transferred to two $6 \mathrm{~mL}$ syringes with 12 in. needles; the needles were then stoppered well. Both syringes were taken out of the glovebox and injected into the prepared Parr reactor against a flow of hydrogen gas. The reaction was stopped after a given amount of time by exposing it to air, and the reactor was allowed to cool down. The catalytic mixture was filtered through a silica plug and toluene was evaporated in vacuo. 
Column chromatography (1:9:90 = triethylamine:acetone:DCM for $N$-phosphinoylamine, 1:10 = hexanes:ethyl acetate for $N$-tosylamine, DCM for cyclic $N$-sulfonylamine) was performed to purify the crude mixture.

(S)- $\boldsymbol{N}$-(1-phenylethyl)-P,P-diphenylphosphinamide (3a). ${ }^{26}$ Off-white crystalline solid. Duplicate average of $35.4 \mathrm{mg}\left(85 \%\right.$ yield). ${ }^{1} \mathrm{H}$ NMR (400 MHz, $\left.\mathrm{CDCl}_{3}\right)$ : $\delta$ 7.93-7.89 (m, 2H), 7.84 - 7.81 (m, 2H), 7.51 - 7.22 (m, 11H), $4.43-4.36(\mathrm{~m}, 1 \mathrm{H}), 3.17$ (dd, $J=9.8,5.7 \mathrm{~Hz}$, $1 \mathrm{H}), 1.58$ (d, $J=6.8 \mathrm{~Hz}, 3 \mathrm{H}) ;{ }^{31} \mathrm{P}\left\{{ }^{1} \mathrm{H}\right\} \mathrm{NMR}\left(121 \mathrm{MHz}, \mathrm{CDCl}_{3}\right): \delta 23.69 ; 98 \%$ ee. Product ratio was determined by HPLC, Chiralpak AD$\mathrm{H}$ column, IPA/Hex = 20:80, $1.0 \mathrm{~mL} / \mathrm{min}, \mathrm{t}_{\mathrm{R}}=8.3 \mathrm{~min}$ (minor), $9.2 \mathrm{~min}$ (major).

(S)- $\boldsymbol{N}$-(1-phenylpropyl)-P,P-diphenylphosphinamide (3b). ${ }^{26}$ Off-white crystalline solid. Duplicate average of $35.2 \mathrm{mg}\left(81 \%\right.$ yield). ${ }^{1} \mathrm{H}$ NMR (400 MHz, $\mathrm{CDCl}_{3}$ ): $\delta$ 7.88-7.85 (m, 2H), 7.77 - 7.73 (m, 2H), 7.50 - 7.14 (m, 11H,), 4.13 - 4.07 (m, $\left.1 \mathrm{H}\right), 3.23$ - 3.20 (dd, J = 9.7, 6.2 Hz, 1H), $2.04-1.98$ (m, 1H), 1.87 - 1.80 (m, 2H), 0.79 (t, $J=7.4 \mathrm{~Hz}, 3 \mathrm{H}) ;{ }^{31} \mathrm{P}\left\{{ }^{1} \mathrm{H}\right\}$ NMR (121 MHz, CDCl $): \delta 23.66 ; 94 \%$ ee. Product ratio was determined by HPLC, Chiralpak AD-H column, IPA/Hex = 20:80, $1.0 \mathrm{~mL} / \mathrm{min}, \mathrm{t}_{\mathrm{R}}=7.5 \mathrm{~min}$ (minor), $9.8 \mathrm{~min}$ (major).

(S)- $\boldsymbol{N}$-(1-naphthalen-1-yl-ethyl)-P,P-diphenylphosphinamide (3c). ${ }^{27}$ Off-white crystalline solid. Duplicate average of $40.9 \mathrm{mg}$ (85\% yield). ${ }^{1} \mathrm{H}$ NMR (400 MHz, $\left.\mathrm{CDCl}_{3}\right): \delta 7.94-7.91(\mathrm{~m}, 2 \mathrm{H}), 7.89-7.83(\mathrm{~m}, 2 \mathrm{H}), 7.79-7.75$ (m, 3H), $7.64-7.62$ (m, $\left.1 \mathrm{H}\right), 7.51-7.36$ (m, $7 \mathrm{H}), 7.28-7.24$ (m, 2H), 5.27 - 5.21 (m, 1H), 3.37 (dd, $J=9.3,5.8 \mathrm{~Hz}, 1 \mathrm{H}), 1.70$ (d, $J=6.7 \mathrm{~Hz}, 3 \mathrm{H}) ;{ }^{31} \mathrm{P}\left\{{ }^{1} \mathrm{H}\right\} \mathrm{NMR}(121 \mathrm{MHz}, \mathrm{CDCl} 3): \delta$ 22.89; 99\% ee. Product ratio was determined by HPLC, Chiralpak AD-H column, IPA/Hex = 20:80, $1.0 \mathrm{~mL} / \mathrm{min}, \mathrm{t}_{\mathrm{R}}=9.0 \mathrm{~min}$ (minor), 13.2 min (major). Single crystals of this compound suitable for X-ray diffraction analysis were obtained by diffusion of hexanes into a saturated dichloromethane solution at room temperature.

(S)- $\boldsymbol{N}$-(2-naphthalen-2-yl-ethyl)-P,P-diphenylphosphinamide (3d). ${ }^{26}$ Yellow crystalline solid. Duplicate average of $37.5 \mathrm{mg}$ (78\% yield). ${ }^{1} \mathrm{H}$ NMR (400 MHz, $\left.\mathrm{CDCl}_{3}\right): \delta$ 7.95-7.91 (m, 2H), 7.85 - 7.77 (m, 5H), $7.68-7.64$ (m, 1H), $7.51-7.41$ (m, $\left.7 \mathrm{H}\right), 7.34-7.31$ (m, 2H), $4.60-4.53(\mathrm{~m}, 1 \mathrm{H}), 3.29$ (dd, $J=9.8,5.8 \mathrm{~Hz}, 1 \mathrm{H}), 1.67$ (d, $J=6.7 \mathrm{~Hz}, 3 \mathrm{H}) ;{ }^{31} \mathrm{P}\left\{{ }^{1} \mathrm{H}\right\} \mathrm{NMR}(121 \mathrm{MHz}, \mathrm{CDCl} 3): \delta 22.66 ; 98 \% e e$. Product ratio was determined by HPLC, Chiralpak AD-H column, IPA/Hex = 20:80, $1.0 \mathrm{~mL} / \mathrm{min}, \mathrm{t}_{\mathrm{R}}=9.1 \mathrm{~min}$ (minor), $9.7 \mathrm{~min}$ (major).

(S)- $\boldsymbol{N}$-(1-(4-chlorophenyl)ethyl)-P,P-diphenylphosphinamide (3e). ${ }^{26}$ Off-white crystalline solid. Duplicate average of $38.7 \mathrm{mg}(84 \%$ yield). ${ }^{1} \mathrm{H}$ NMR (400 MHz, $\left.\mathrm{CDCl}_{3}\right): \delta$ 7.92-7.88 (m, 2H), $7.82-7.78(\mathrm{~m}, 2 \mathrm{H}), 7.52-7.36$ (m, 6H), $7.28-7.21$ (m, $\left.4 \mathrm{H}\right), 4.41-4.34(\mathrm{~m}$, $1 \mathrm{H}), 3.19$ (dd, $J=9.8,5.7 \mathrm{~Hz}, 1 \mathrm{H}), 1.56(\mathrm{~d}, J=6.7 \mathrm{~Hz}, 3 \mathrm{H}) ;{ }^{31} \mathrm{P}\left\{{ }^{1} \mathrm{H}\right\} \mathrm{NMR}\left(121 \mathrm{MHz}, \mathrm{CDCl}_{3}\right): \delta 23.18$; $98 \%$ ee. Product ratio was determined by HPLC, Chiralpak AD-H column, IPA/Hex = 15:85, $1.0 \mathrm{~mL} / \mathrm{min}, \mathrm{t}_{\mathrm{R}}=12.2 \mathrm{~min}$ (minor), 12.9 min (major).

(S)- $\boldsymbol{N}$-(1-(3-chlorophenyl)ethyl)-P,P-diphenylphosphinamide (3f). ${ }^{45}$ Off-white crystalline solid. Duplicate average of $37.0 \mathrm{mg}$ (81\% yield). ${ }^{1} \mathrm{H}$ NMR (400 MHz, $\left.\mathrm{CDCl}_{3}\right): \delta$ 7.93-7.87 (m, 2H), $7.83-7.77$ (m, 2H), $7.53-7.35$ (m, 6H), $7.25-7.14$ (m, $\left.4 \mathrm{H}\right), 4.42-4.32(\mathrm{~m}$, $1 \mathrm{H}), 3.14$ (dd, $J=9.7,5.6 \mathrm{~Hz}, 1 \mathrm{H}), 1.56(\mathrm{~d}, J=6.8 \mathrm{~Hz}, 3 \mathrm{H}) ;{ }^{31} \mathrm{P}\left\{{ }^{1} \mathrm{H}\right\} \mathrm{NMR}\left(121 \mathrm{MHz}, \mathrm{CDCl}_{3}\right): \delta 22.64 ; 94 \%$ ee. Product ratio was determined by HPLC, Chiralpak AD-H column, IPA/Hex = 20:80, $1.0 \mathrm{~mL} / \mathrm{min}, \mathrm{t}_{\mathrm{R}}=6.1 \mathrm{~min}$ (minor), 8.7 min (major).

(S)-N-(1-(4-methoxyphenyl)ethyl)-P,P-diphenylphosphinamide (3g). ${ }^{26}$ Off-white crystalline solid. Duplicate average of $34.4 \mathrm{mg}(76 \%$ yield). ${ }^{1} \mathrm{H}$ NMR (400 MHz, $\left.\mathrm{CDCl}_{3}\right): \delta$ 7.91-7.88 (m, 2H), $7.84-7.81$ (m, 2H), $7.50-7.34(\mathrm{~m}, 6 \mathrm{H}), 7.24-7.18(\mathrm{~m}, 2 \mathrm{H}), 6.86-6.80(\mathrm{~m}$, 2H), 4.38 - 4.32 (m, 1H), 3.15 (dd, $J=9.6,5.9 \mathrm{~Hz}, 1 \mathrm{H}), 1.55$ (d, $J=6.8 \mathrm{~Hz}, 3 \mathrm{H}) ;{ }^{31} \mathrm{P}\left\{{ }^{1} \mathrm{H}\right\} \mathrm{NMR}\left(121 \mathrm{MHz}, \mathrm{CDCl}_{3}\right): \delta 22.78 ; 96 \% e e$. Product ratio was determined by HPLC, Chiralpak AD-H column, IPA/Hex = 20:80, $1.0 \mathrm{~mL} / \mathrm{min}, \mathrm{t}_{\mathrm{R}}=9.7 \mathrm{~min}$ (minor), $10.7 \mathrm{~min}$ (major).

(S)-N-(1-(2-methoxyphenyl)ethyl)-P,P-diphenylphosphinamide (3h). ${ }^{26}$ Yellow crystalline solid. Duplicate average of $33.6 \mathrm{mg}(74 \%$ yield). ${ }^{1} \mathrm{H}$ NMR (400 MHz, $\left.\mathrm{CDCl}_{3}\right): \delta 7.88-7.84(\mathrm{~m}, 2 \mathrm{H}), 7.82-7.76$ (m, 2H), $7.49-7.38$ (m, 4H), $7.36-7.31$ (m, $\left.2 \mathrm{H}\right), 7.23-7.21$ (m, 1H), $7.06-7.05$ (m, 1H), 6.90 - 6.85 (m, 2H), $4.50-4.44$ (m, 1H), 3.93 (dd, $J=11.0,7.8$ Hz, 1H), 3.75 (s, 3H, OCH3), 1.57 (d, $J=6.8$ Hz, $3 \mathrm{H}) ;{ }^{31} \mathrm{P}\left\{{ }^{1} \mathrm{H}\right\}$ NMR (121 MHz, $\left.\mathrm{CDCl}_{3}\right): \delta$ 22.94; 96\% ee. Product ratio was determined by HPLC, Chiralpak AD-H column, IPA/Hex = 10:90, $1.0 \mathrm{~mL} / \mathrm{min}, \mathrm{t}_{\mathrm{R}}=22.5 \mathrm{~min}$ (major), $23.9 \mathrm{~min}$ (minor).

(S)- $\mathbf{N}$-(1-furylethyl)-P,P-diphenylphosphinamide (3i). ${ }^{26}$ Yellow crystalline solid. Duplicate average of $23.4 \mathrm{mg}\left(58 \%\right.$ yield). ${ }^{1} \mathrm{H} \mathrm{NMR}$ (400 MHz, $\left.\mathrm{CDCl}_{3}\right): \delta 7.97-7.86(\mathrm{~m}, 4 \mathrm{H}), 7.51-7.40$ (m, 6H), 7.35 (dd, $\left.J=1.9,0.9 \mathrm{~Hz}, 1 \mathrm{H}\right), 6.28$ (dd, $\left.J=3.17,1.88 \mathrm{~Hz}, 1 \mathrm{H}\right), 6.13(\mathrm{dt}, J=$ 3.1, $0.8 \mathrm{~Hz}, 1 \mathrm{H}), 4.45$ - $4.36(\mathrm{~m}, 1 \mathrm{H}), 3.35-3.30(\mathrm{~m}, 1 \mathrm{H}), 1.60$ (d, $J=6.8 \mathrm{~Hz}, 3 \mathrm{H}) ;{ }^{31} \mathrm{P}\left\{{ }^{1} \mathrm{H}\right\} \mathrm{NMR}\left(121 \mathrm{MHz}, \mathrm{CDCl}_{3}\right): \delta 22.85 ; 92 \% e e$. Product ratio was determined by HPLC, Chiralpak AD-H column, IPA/Hex = 20:80, $1.0 \mathrm{~mL} / \mathrm{min}, \mathrm{t}_{\mathrm{R}}=6.9 \mathrm{~min}$ (major), $7.8 \mathrm{~min}$ (minor).

(S)- $N$-(1-thiophenylethyl)-P,P-diphenylphosphinamide (3j). ${ }^{26}$ Off-white crystalline solid. Duplicate average of $34.6 \mathrm{mg}\left(82 \%\right.$ yield). ${ }^{1} \mathrm{H}$ NMR (400 MHz, $\mathrm{CDCl}_{3}$ ): $\delta$ 7.98-7.93 (m, 4H), 7.52 - 7.41 (m, 6H), 7.21 (dd, J = 5.0, $\left.1.3 \mathrm{~Hz}, 1 \mathrm{H}\right), 6.94-6.91$ (m, $2 \mathrm{H}$ ), $4.62-4.55$ (m, $1 \mathrm{H}$ ), 3.25 (dd, $J=10.8,5.4 \mathrm{~Hz}, 1 \mathrm{H}), 1.70(\mathrm{~d}, J=6.7 \mathrm{~Hz}, 3 \mathrm{H}) ;{ }^{31} \mathrm{P}\left\{{ }^{1} \mathrm{H}\right\} \mathrm{NMR}\left(121 \mathrm{MHz}, \mathrm{CDCl}_{3}\right): \delta 22.44 ; 95 \%$ ee. Product ratio was determined 
by HPLC, Chiralpak AD-H column, IPA/Hex = 20:80, $1.0 \mathrm{~mL} / \mathrm{min}, \mathrm{t}_{\mathrm{R}}=8.6 \mathrm{~min}$ (major), $9.4 \mathrm{~min}$ (minor). Single crystals of this compound suitable for X-ray diffraction analysis were obtained by diffusion of hexanes into a saturated dichloromethane solution at room temperature.

(S)-N-(1-(2-chlorothiophenyl)ethyl)-P,P-diphenylphosphinamide (3k). ${ }^{26}$ Yellow crystalline solid. Duplicate average of $27.7 \mathrm{mg}$ (59\% yield). ${ }^{1} \mathrm{H}$ NMR (400 MHz, $\left.\mathrm{CDCl}_{3}\right): \delta$ 7.94-7.88 (m, 4H), $7.50-7.38(\mathrm{~m}, 6 \mathrm{H}), 6.72(\mathrm{~d}, J=3.8 \mathrm{~Hz}, 1 \mathrm{H}) 6.66(\mathrm{dd}, J=3.8,1.1 \mathrm{~Hz}, 1 \mathrm{H}), 4.48$ - 4.38 (m, 1H), 3.40 (dd, $J=10.7,5.3 \mathrm{~Hz}, 1 \mathrm{H}), 1.62$ (d, $J=6.6 \mathrm{~Hz}, 3 \mathrm{H}) ;{ }^{31} \mathrm{P}\left\{{ }^{1} \mathrm{H}\right\}$ NMR $(121 \mathrm{MHz}, \mathrm{CDCl}$ ): $\delta 22.71 ; 90 \%$ ee. Product ratio was determined by HPLC, Chiralpak AD-H column, IPA/Hex = 20:80, $1.0 \mathrm{~mL} / \mathrm{min}, \mathrm{t}_{\mathrm{R}}=6.4 \mathrm{~min}$ (minor), $7.4 \mathrm{~min}$ (major).

$\boldsymbol{N}$-(1-indanyl)-P,P-diphenylphosphinamide (3l). ${ }^{26}$ Off-white crystalline solid. Duplicate average of $17.8 \mathrm{mg}\left(41 \%\right.$ yield). ${ }^{1} \mathrm{H}$ NMR (400 $\mathrm{MHz}_{\mathrm{CDCl}}$ ): $\delta$ 8.04-7.95 (m, 4H), 7.70 - $7.72(\mathrm{~m}, 1 \mathrm{H}), 7.53$ - $7.44(\mathrm{~m}, 6 \mathrm{H}), 7.24-7.18(\mathrm{~m}, 3 \mathrm{H}), 4.73-4.63(\mathrm{~m}, 1 \mathrm{H}), 3.24(\mathrm{dd}, J=11.4$, $6.4 \mathrm{~Hz}, 1 \mathrm{H}), 2.96$ (ddd, $J=15.8,8.7,2.8 \mathrm{~Hz}, 1 \mathrm{H}), 2.80-2.72(\mathrm{~m}, 1 \mathrm{H}), 2.65-2.56(\mathrm{~m}, 1 \mathrm{H}), 2.04-1.94(\mathrm{~m}, 1 \mathrm{H}) ;{ }^{31} \mathrm{P}\left\{{ }^{1} \mathrm{H}\right\} \mathrm{NMR}(121 \mathrm{MHz}$, $\mathrm{CDCl}_{3}$ ): $\delta$ 22.48; 79\% ee. Product ratio was determined by HPLC, Chiralpak AD-H column, IPA/Hex $=20: 80,1.0 \mathrm{~mL} / \mathrm{min}, \mathrm{t}_{\mathrm{R}}=8.2 \mathrm{~min}$ (minor), 9.4 min (major).

$N$-(1-(methyl)pentylidene)-diphenylphosphinamide (3m). ${ }^{26}$ Off-white crystalline solid. Duplicate average of $5.7 \mathrm{mg}\left(14 \%\right.$ yield). ${ }^{1} \mathrm{H}$ NMR (400 MHz, $\left.\mathrm{CDCl}_{3}\right): \delta 7.94-7.88(\mathrm{~m}, 4 \mathrm{H}), 7.49-7.42(\mathrm{~m}, 6 \mathrm{H}), 3.22$ - $3.12(\mathrm{~m}, 1 \mathrm{H}), 2.67-2.63$ (m, $\left.1 \mathrm{H}\right), 1.56-1.08$ (m, $\left.11 \mathrm{H}\right), 0.86$ (t, $J=7.1 \mathrm{~Hz}, 3 \mathrm{H}) ;{ }^{31} \mathrm{P}\left\{{ }^{1} \mathrm{H}\right\}$ NMR (121 MHz, $\left.\mathrm{CDCl}_{3}\right): \delta$ 22.04; 35\% ee. Product ratio was determined by HPLC, Chiralpak AD-H column, IPA/Hex = 15:85, $1.0 \mathrm{~mL} / \mathrm{min}, \mathrm{t}_{\mathrm{R}}=9.7 \mathrm{~min}$ (minor), $7.3 \mathrm{~min}$ (major).

(S)- $N$-(1-phenylethyl)-4-methyl-benzenesulfonamide (5a). ${ }^{\mathbf{1 8}}$ Off-white crystalline solid. Duplicate average of $29.1 \mathrm{mg}\left(82 \%\right.$ yield). ${ }^{1} \mathrm{H}$ NMR (400 MHz, CDCl $): \delta 7.64-7.60$ (m, 2H), 7.22 - 7.17 (m, 5H), 7.16 - $7.11(\mathrm{~m}, 2 \mathrm{H}), 4.79-4.72(\mathrm{~m}, 1 \mathrm{H}), 4.48$ - $4.38(\mathrm{~m}, 1 \mathrm{H}), 2.39(\mathrm{~s}$, 3H) 1.43 (d, $J=6.8 \mathrm{~Hz}, 3 \mathrm{H}) ; 97 \%$ ee. Product ratio was determined by HPLC, Chiralpak AD-H column, IPA/Hex = 10:90, 1.0 mL/min, $\mathrm{t}_{\mathrm{R}}=$ $12.8 \mathrm{~min}$ (minor), $14.1 \mathrm{~min}$ (major). Single crystals of this compound suitable for X-ray diffraction analysis were obtained by diffusion of hexanes into a saturated dichloromethane solution at room temperature.

3-Methyl-1,2-benzisothiazoline 1,1-Dioxide (5b). ${ }^{\mathbf{1 8}}$ Off-white crystalline solid. Duplicate average of $5.5 \mathrm{mg}$ (26\% yield). ${ }^{1} \mathrm{H}$ NMR (400 $\mathrm{MHz}_{\mathrm{CDCl}}$ ): $\delta 7.78(\mathrm{~d}, J=7.8 \mathrm{~Hz}, 1 \mathrm{H}) 7.62-7.66(\mathrm{~m}, 1 \mathrm{H}), 7.53(\mathrm{t}, J=7.5 \mathrm{~Hz}, 1 \mathrm{H}), 7.40(\mathrm{~d}, J=7.8 \mathrm{~Hz}, 1 \mathrm{H}), 4.83-4.76(\mathrm{~m}, 1 \mathrm{H}), 4.64(\mathrm{br}$ s, $1 \mathrm{H}$ ), 1.63 (d, $J=6.7 \mathrm{~Hz}, 3 \mathrm{H}$ ); 55\% ee. Product ratio was determined by HPLC, Chiralpak AD-H column, IPA/Hex = 15:85, 1.0 mL/min, $\mathrm{t}_{\mathrm{R}}=12.5 \mathrm{~min}$ (major), $13.5 \mathrm{~min}$ (minor).

DFT calculations. Density functional theory calculations were performed using the Gaussian09 package ${ }^{46}$ and the M11-L hybrid functional. All atoms were treated with the 6-31G* basis set while iron was treated with the Stuttgart effective core potential SDD. A toluene solvation model was applied. Complete details can be found in the SI.

\section{ASSOCIATED CONTENT}

\section{Supporting Information}

The Supporting Information is available free of charge on the ACS Publications website. A PDF file of HPLC traces of the products. X-ray crystal structures and absolute configuration determinations of $\mathbf{3 c}$, $\mathbf{3 j}$, and $\mathbf{5 a}$. DFT calculation details and supplementary figures. A file of the DFT calculated coordinates and energies and, in the case of transition states, the imaginary frequency. The crystallographic cif files have been deposited as CCDC 1903117-1903119.

\section{AUTHOR INFORMATION}

Corresponding Author

*rmorris@chem.utoronto.ca

ORCID

Chris Sang G. Seo: 0000-0002-5519-4127

Robert H. Morris: 0000-0002-7574-9388 


\section{Notes}

The authors declare no competing financial interests.

\section{ACKNOWLEDGMENT}

NSERC Canada is thanked for a Discovery Grant to R. H. M. thanks NSERC Canada for a Discovery Grant and Compute Canada for an Allocation Grant to access Sharcnet.ca.

\section{REFERENCES}

(1) Seo, C. S. G.; Morris, R. H., Catalytic Homogeneous Asymmetric Hydrogenation: Successes and Opportunities. Organometallics 2019, 38, 47-65.

(2) Zhang, Z. F.; Butt, N. A.; Zhang, W. B., Asymmetric Hydrogenation of Nonaromatic Cyclic Substrates. Chem. Rev. 2016, 116, 14769-14827.

(3) Drommia, D.; Arena, C. G. Recent Advances on Chiral Catalysts for Asymmetric Hydrogenation of C=C, C=N and C=O Bonds. In Curr. Org. Chem.; Bentham Science Publishers B.V.: 2016; Vol. 20, p 2552-2590.

(4) Hopmann, K. H.; Bayer, A., Enantioselective Imine Hydrogenation with Iridium-Catalysts: Reactions, Mechanisms and Stereocontrol. Coord. Chem. Rev. 2014, 268, 59-82.

(5) Ager, D. J.; de Vries, A. H. M.; de Vries, J. G., Asymmetric Homogeneous Hydrogenations at Scale. Chem. Soc. Rev. 2012, 41, 3340-3380.

(6) Fleury-Bregeot, N.; de la Fuente, V.; Castillon, S.; Claver, C., Highlights of Transition Metal-Catalyzed Asymmetric Hydrogenation of Imines. Chemcatchem 2010, 2, 1346-1371.

(7) Xie, J. H.; Zhu, S. F.; Zhou, Q. L., Transition Metal-catalyzed Enantioselective Hydrogenation of Enamines and Imines. Chem. Rev. 2011, 111, 1713-1760.

(8) Hogan, P. C.; Chen, C.-L.; Mulvihill, K. M.; Lawrence, J. F.; Moorhead, E.; Rickmeier, J.; Myers, A. G., Large-scale Preparation of Key Building Blocks for the Manufacture of Fully Synthetic Macrolide Antibiotics. J. Antibiot. 2018, 71, 318-325.

(9) Blaser, H. U.; Pugin, B.; Spindler, F.; Thommen, M., From a Chiral Switch to a Ligand Portfolio for Asymmetric Catalysis. Acc. Chem. Res. 2007, 40, 1240-1250.

(10) Verzijl, G. K. M.; De Vries, A. H. M.; De Vries, J. G.; Kapitan, P.; Dax, T.; Helms, M.; Nazir, Z.; Skranc, W.; Imboden, C.; Stichler, J.; Ward, R. A.; Abele, S.; Lefort, L., Catalytic Asymmetric Reduction of a 3,4-Dihydroisoquinoline for the Large-Scale Production of Almorexant: Hydrogenation or Transfer Hydrogenation? Org. Process Res. Dev. 2013, 17, 1531-1539.

(11) Wei, X. D.; Qu, B.; Zeng, X. Z.; Savoie, J.; Fandrick, K. R.; Desrosiers, J. N.; Tcyrulnikov, S.; Marsini, M. A.; Buono, F. G.; Li, Z. B.; Yang, B. S.; Tang, W. J.; Haddad, N.; Gutierrez, O.; Wang, J.; Lee, H. W.; Ma, S. L.; Campbell, S.; Lorenz, J. C.; Eckhardt, M.; Himmelsbach, F.; Peters, S.; Patel, N. D.; Tan, Z. L.; Yee, N. K.; Song, J. J.; Roschangar, F.; Kozlowski, M. C.; Senanayake, C. H., Sequential C-H Arylation and Enantioselective Hydrogenation Enables Ideal Asymmetric Entry to the Indenopiperidine Core of an $11 \beta$-HSD-1 Inhibitor. J. Am. Chem. Soc. 2016, 138, 15473-15481.

(12) Ružič, M.; Pečavar, A.; Prudič, D.; Kralj, D.; Scriban, C.; Zanotti-Gerosa, A., The Development of an Asymmetric Hydrogenation Process for the Preparation of Solifenacin. Org. Process Res. Dev. 2012, 16, 1293-1300.

(13) Strotman, N. A.; Ramirez, A.; Simmons, E. M.; Soltani, O.; Parsons, A. T.; Fan, Y.; Sawyer, J. R.; Rosner, T.; Janey, J. M.; Tran, K.; Li, J.; La Cruz, T. E.; Pathirana, C.; Ng, A. T.; Deerberg, J., Enantioselective Synthesis of a $\gamma$-Secretase Modulator via Vinylogous Dynamic Kinetic Resolution. J. Org. Chem. 2018, 83, 11133-11144.

(14) Nedden, H. G.; Zanotti-Gerosa, A.; Wills, M., The Development of Phosphine-Free Tethered Ruthenium(II) Catalysts for the Asymmetric Reduction of Ketones and Imines. Chem. Rec. 2016, 16, 2623-2643.

(15) Mangion, I. K.; Chen, C.-y.; Li, H.; Maligres, P.; Chen, Y.; Christensen, M.; Cohen, R.; Jeon, I.; Klapars, A.; Krska, S.; Nguyen, H.; Reamer, R. A.; Sherry, B. D.; Zavialov, I., Enantioselective Synthesis of an HCV NS5a Antagonist. Org. Lett. 2014, 16, 2310-2313. 
(16) Spindler, F.; Blaser, H.-U., The Highly Enantioselective Hydrogenation of N-Diphenylphosphinylketimines with Cationic Rh Ferrocenyldiphosphine Catalysts. Adv. Synth. Catal. 2001, 343, 68-70.

(17) Wang, Y.-Q.; Zhou, Y.-G., Highly Enantioselective Pd-Catalyzed Asymmetric Hydrogenation of N-Diphenylphosphinyl Ketimines. Synlett 2006, 2006, 1189-1192.

(18) Wang, Y.-Q.; Lu, S.-M.; Zhou, Y.-G., Highly Enantioselective Pd-catalyzed Asymmetric Hydrogenation of Activated Imines. J. Org. Chem. 2007, 72, 3729-3734.

(19) Yang, Q.; Shang, G.; Gao, W.; Deng, J.; Zhang, X., A Highly Enantioselective, Pd-TangPhos-catalyzed Hydrogenation of Ntosylimines. Angew. Chem. Int. Ed. 2006, 45, 3832-3835.

(20) Yu, C.-B.; Wang, D.-W.; Zhou, Y.-G., Highly Enantioselective Synthesis of Sultams via Pd-Catalyzed Hydrogenation. J. Org. Chem. 2009, 74, 5633-5635.

(21) Zhou, X. Y.; Bao, M.; Zhou, Y. G., Palladium-Catalyzed Asymmetric Hydrogenation of Simple Ketimines Using a Bronsted Acid as Activator. Adv. Syn. Catal. 2011, 353, 84-88.

(22) Ma, X.; Qiao, L.; Liu, G.; Huang, Z., A New Phosphine-Amine-Oxazoline Ligand for Ru-Catalyzed Asymmetric Hydrogenation of N-Phosphinylimines. Chin. J. Chem. 2018, 36, 1151-1155.

(23) Zhou, S. L.; Fleischer, S.; Junge, K.; Beller, M., Cooperative Transition-Metal and Chiral Bronsted Acid Catalysis: Enantioselective Hydrogenation of Imines To Form Amines. Angew. Chem. Int. Ed. 2011, 50, 5120-5124.

(24) Lagaditis, P. O.; Sues, P. E.; Sonnenberg, J. F.; Wan, K. Y.; Lough, A. J.; Morris, R. H., Iron(II) Complexes Containing Unsymmetrical P-N-P' Pincer Ligands for the Catalytic Asymmetric Hydrogenation of Ketones and Imines. J. Am. Chem. Soc. 2014, 136, 1367-1380.

(25) Bai, X. S.; Cettolin, M.; Mazzoccanti, G.; Pierini, M.; Piarulli, U.; Colombo, V.; Dal Corso, A.; Pignataro, L.; Gennari, C., Chiral (cyclopentadienone)Iron Complexes with a Stereogenic Plane as Pre-catalysts for the Asymmetric Hydrogenation of Polar Double Bonds. Tetrahedron 2019, 75, 1415-1424.

(26) Zhou, S.; Fleischer, S.; Junge, K.; Das, S.; Addis, D.; Beller, M., Enantioselective Synthesis of Amines: General, Efficient Ironcatalyzed Asymmetric Transfer Hydrogenation of Imines. Angew. Chem. Int. Ed. 2010, 49, 8121-8125.

(27) Mikhailine, A. A.; Maishan, M. I.; Morris, R. H., Asymmetric Transfer Hydrogenation of Ketimines Using Well-Defined Iron(II)Based Precatalysts Containing a PNNP Ligand. Org. Lett. 2012, 14, 4638-4641.

(28) Zuo, W.; Lough, A. J.; Li, Y. F.; Morris, R. H., Amino(imino)diphosphines Activate Iron Catalysts in the Asymmetric Transfer Hydrogenation of Ketones and Imines Science 2013, 342, 1080-1083.

(29) Bigler, R.; Mezzetti, A., Highly Enantioselective Transfer Hydrogenation of Polar Double Bonds by Macrocyclic Iron(II)/(NH) $2 \mathrm{P}_{2}$ Catalysts. Org. Process Res. Dev. 2016, 20, 253-261.

(30) Sugi, K. D.; Nagata, T.; Yamada, T.; Mukaiyama, T., Enantioselective Borohydride Reduction of N-diphenylphosphinyl Imines Using Optically Active Cobalt(II) Complex Catalysts. Chem. Lett. 1997, 493-494.

(31) Yamada, T.; Nagata, T.; Ikeno, T.; Ohtsuka, Y.; Sagara, A.; Mukaiyama, T., Optically Active $\beta$-ketoiminato Cobalt(II) Complexes as Highly Efficient Catalysts in Enantioselective Borohydride Reduction of Ketones, Imines, and $\alpha, \beta$-unsaturated Carboxylates. Inorg. Chim. Acta 1999, 296, 86-93.

(32) Xu, H.; Yang, P.; Chuanprasit, P.; Hirao, H.; Zhou, J., Nickel-Catalyzed Asymmetric Transfer Hydrogenation of Hydrazones and Other Ketimines. Angew. Chem. Int. Ed. 2015, 54, 5112-5116.

(33) Smith, S. A. M.; Lagaditis, P. O.; Lüpke, A.; Lough, A. J.; Morris, R. H., Unsymmetrical Iron P-NH-P' Catalysts for the Asymmetric Pressure Hydrogenation of Aryl Ketones. Chem. - Eur. J. 2017, 23, 7212-7216.

(34) Graves, C. R.; Scheidt, K. A.; Nguyen, S. T., Enantioselective MSPV Reduction of Ketimines Using 2-Propanol and (BINOL)Al ${ }^{\mathrm{III}}$. Org. Lett. 2006, 8, 1229-1232.

(35) Sonnenberg, J. F.; Sues, P. E.; Wan, K. Y.; Morris, R. H., Ketone Asymmetric Hydrogenation Catalyzed by P-NH-P’ Pincer Iron Catalysts: an Experimental and Computational Study. ACS Catal. 2017, 7, 316-326.

(36) Clapham, S. E.; Hadzovic, A.; Morris, R. H., Mechanisms of the $\mathrm{H}_{2}$-Hydrogenation and Transfer Hydrogenation of Polar Bonds Catalyzed by Ruthenium Hydride Complexes. Coord. Chem. Rev. 2004, 248, 2201-2237. 
(37) Bellows, S. M.; Chakraborty, S.; Gary, J. B.; Jones, W. D.; Cundari, T. R., An Uncanny Dehydrogenation Mechanism: Polar Bond Control over Stepwise or Concerted Transition States. Inorg. Chem. 2017, 56, 5519-5524.

(38) Hopmann, K. H., Iron/Brønsted Acid Catalyzed Asymmetric Hydrogenation: Mechanism and Selectivity-Determining Interactions. Chem. - Eur. J. 2015, 21, 10020-10030.

(39) Armarego, W. L. F.; Chai, C. L. L., 2009, Purification of Laboratory Chemicals, 6th Ed. ed.; Butterworth-Heinemann: Oxford, .

(40) Lai, P.-S.; Dubland, J. A.; Sarwar, M. G.; Chudzinski, M. G.; Taylor, M. S., Carbon-carbon Bond-forming Reactions of $\alpha$-carbonyl Carbocations: Exploration of a Reversed-polarity Equivalent of Enolate Chemistry. Tetrahedron 2011, 67, 7586-7592.

(41) Abdur-Rashid, K.; Lough, A. J.; Morris, R. H., RuHCl(diphosphine)(diamine): Catalyst Precursors for the Stereoselective Hydrogenation of Ketones and Imines. Organometallics 2001, 20, 1047-1049.

(42) Bezłada, A.; Szewczyk, M.; Mlynarski, J., Enantioselective Hydrosilylation of Imines Catalyzed by Chiral Zinc Acetate Complexes. J. Org. Chem. 2015, 81, 336-342.

(43) Chen, Y.-J.; Chen, C., Enantioselective Strecker-type reaction of phosphinoyl ketimines catalyzed by a chiral Zr-bipyridyldiol catalyst. Tetrahedron: Asym. 2008, 19, 2201-2209.

(44) Reingruber, R.; Bräse, S., 1,2-Addition of Trialkylaluminium Reagents to $N$-diphenylphosphinoylketimines in the Absence of Any Additional Reagents. Chem. Commun. 2008, 105-107.

(45) Crampton, R. H.; Hajjaji, S. E.; Fox, M. E.; Woodward, S., Reaction Prospecting by ${ }^{31}$ P NMR: Enantioselective Rhodium-DuPhos Catalysed Addition of ZnMez to Diphenylphosphinoylimines. Tetrahedron: Asym. 2009, 20, 2497-2503.

(46) Frisch, M. J.; Trucks, G. W.; Schlegel, H. B.; Scuseria, G. E.; Robb, M. A.; Cheeseman, J. R.; Scalmani, G.; Barone, V.; Mennucci, B.; Petersson, G. A.; Nakatsuji, H.; Caricato, M.; Li, X.; Hratchian, H. P.; Izmaylov, A. F.; Bloino, J.; Zheng, G.; Sonnenberg, J. L.; Hada, M.; Ehara, M.; Toyota, K.; Fukuda, R.; Hasegawa, J.; Ishida, M.; Nakajima, T.; Honda, Y.; Kitao, O.; Nakai, H.; Vreven, T.; Montgomery, J. A.; Peralta, J. E.; Ogliaro, F.; Bearpark, M.; Heyd, J. J.; Brothers, E.; Kudin, K. N.; Staroverov, V. N.; Kobayashi, R.; Normand, J.; Raghavachari, K.; Rendell, A.; Burant, J. C.; Iyengar, S. S.; Tomasi, J.; Cossi, M.; Rega, N.; Millam, J. M.; Klene, M.; Knox, J. E.; Cross, J. B.; Bakken, V.; Adamo, C.; Jaramillo, J.; Gomperts, R.; Stratmann, R. E.; Yazyev, O.; Austin, A. J.; Cammi, R.; Pomelli, C.; Ochterski, J. W.; Martin, R. L.; Morokuma, K.; Zakrzewski, V. G.; Voth, G. A.; Salvador, P.; Dannenberg, J. J.; Dapprich, S.; Daniels, A. D.; Farkas, Ö.; Foresman, J. B.; Ortiz, J. V.; Cioslowski, J.; Fox, D. J., Gaussian 09. 2009, Gaussian 09. Revision D.01. 